\title{
34 Vragen en antwoorden over steekmuggen en knutten in relatie tot vernatting
}

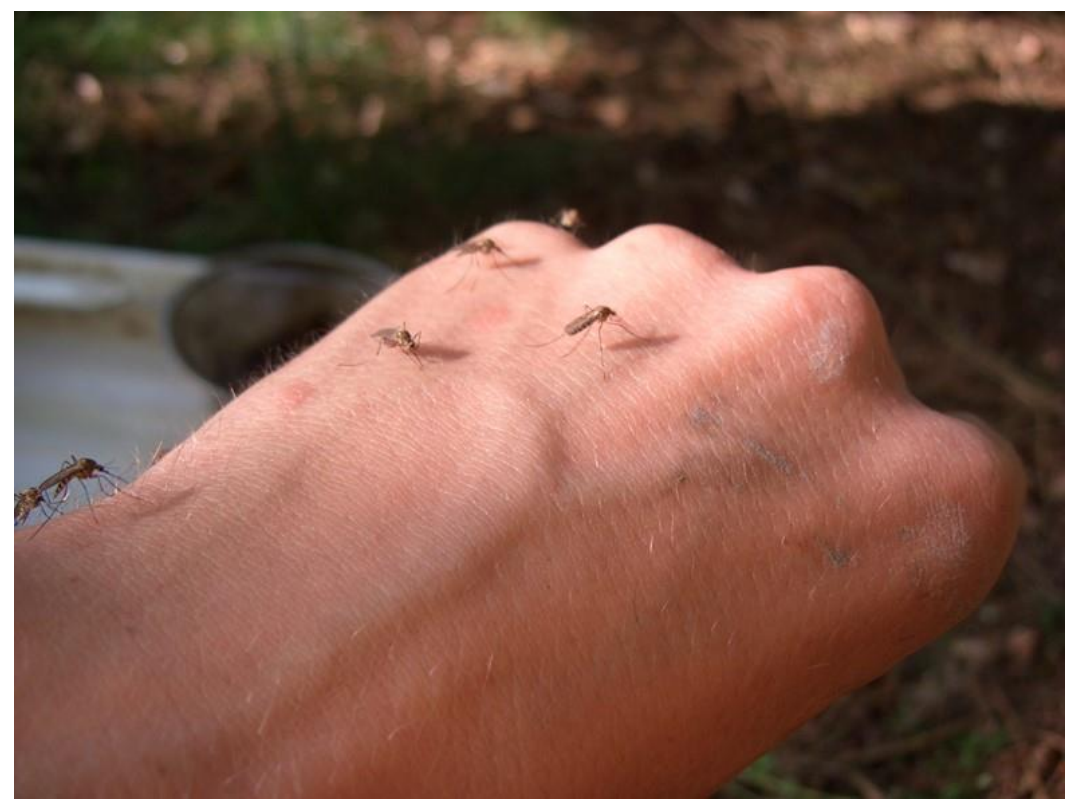

Piet F.M. Verdonschot

Zoetwaterecosystemen, Wageningen Environmental Research

Augustus 2018 


\section{Auteurs}

Piet F.M. Verdonschot (correspondentie: piet.verdonschot@wur.nI)

\section{Opdrachtgever}

Provincie Overijssel

Projectgroep

Namen

\section{Wijze van citeren}

Verdonschot P.F.M. (2018) 34 Vragen en antwoorden over steekmuggen en knutten in relatie tot vernatting. Notitie Zoetwaterecosystemen, Wageningen Environmental Research, Wageningen UR, Wageningen. 35 pp.

\section{Trefwoorden}

steekmug, knut, verspreiding, overlast, vernatting, ziekte, maatregel

\section{Beeldmateriaal}

Rink Wiggers

https://doi.org/10.18174/565518

Dit project is uitgevoerd in opdracht van de Provincie Overijssel

(C) 2018 Zoetwaterecosystemen, Wageningen Environmental Research

- Overname, verveelvoudiging of openbaarmaking van deze uitgave is toegestaan mits met duidelijke bronvermelding.

- Overname, verveelvoudiging of openbaarmaking is niet toegestaan voor commerciële doeleinden en/of geldelijk gewin.

- Overname, verveelvoudiging of openbaarmaking is niet toegestaan voor die gedeelten van deze uitgave waarvan duidelijk is dat de auteursrechten liggen bij derden en/of zijn voorbehouden.

Wageningen Environmental Research aanvaardt geen aansprakelijkheid voor eventuele schade voortvloeiend uit het gebruik van de resultaten van dit onderzoek of de toepassing van de adviezen.

\section{Notitie Zoetwaterecosystemen, Wageningen Environmental Research}

Wageningen, oktober 2018 


\section{Inhoud}

$1 \quad$ Inleiding, doel en werkwijze $\quad 5$

1.1 Achtergrond $\quad 5$

1.2 Probleemstelling 6

1.3 Vraagstelling en doel $\quad 6$

1.4 Werkwijze 6

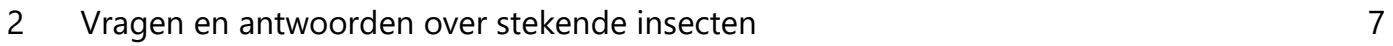

Vraag 1: Wat is de verspreiding van steekmuggen en knutten in Nederland? $\quad 7$

Vraag 2: Waar leven de larven van steekmuggen en knutten? $\quad 7$

Vraag 3: Waar leven volwassen steekmuggen en knutten? 8

Vraag 4: Komen steekmuggen en knutten ook voor in beken? 8

Vraag 5: Waarom zijn steekmuggen en knutten vaak talrijk in moerasgebieden? 9

Vraag 6: Komen er ook steekmuggen voor in een vijver met permanent water? 9

Vraag 7: Op welke plaatsen gedijen steekmuggen goed? 9

Vraag 8: Wat is de rol van droogval bij optreden van steekmuggen en knutten? 10

Vraag 9: Hoe ver verspreiden steekmuggen en knutten zich? 11

Vraag 10: Hoe snel en wanneer ontwikkelen steekmuggen en knutten zich? 11

Vraag 11: Wat is de invloed van voedselrijkdom op de ontwikkeling van larven? 12

Vraag 12: Hoe groot is de actieradius van steekmuggen en knutten? 13

Vraag 13: Welke invloed heeft het weer (bv. wind) op de actieradius? 13

Vraag 14: Hoe verspreiden volwassen stekende insecten zich i.r.t. begroeiing? 14

Vraag 15: Hoe beïnvloedt een broedgebied de aantallen stekende insecten? 15

Vraag 16: Wanneer is sprake van overlast? 15

Vraag 17: Dragen steekmuggen ziekten over? 16

Vraag 18: Hoe gevaarlijk is de loodgrijze malariamug? 17

Vraag 19: Welk percentage knutten is drager van Blauwtong en Schmallenberg? 17

Vraag 20: Levert vernatting extra risico op voor vogelpest? 18

Vraag 21: Zijn inentingen en preventieve maatregelen mogelijk? 18

Vraag 22: Levert vernatting extra overlast op voor recreanten? 19

Vraag 23: Waardoor is er vaak sprake van overlast rond bebouwing? 19

Vraag 24: Treedt er verschil op tussen de bestaande en toekomstige natuur? 20

Vraag 25: Zijn maatregelen mogelijk als er gegronde risico's ontstaan? 20

Vraag 26: Hoe kan ik op fysieke omstandigheden (bij)sturen? $\quad 21$

Vraag 27: Hoe kan ik op waterkwaliteit sturen? 22

Vraag 28: Kan ik sturen op predatoren van steekmuggen en knutten? 22

Vraag 29: Moet ik extra maatregelen nemen vlak na een (her)inrichting? 22

Vraag 30: Heeft het terreinbeheer invloed op steekmuggen en knutten? 23

Vraag 31: Hoe zit het met kriebelmuggen in Nederland? 24

Vraag 32: Kunnen we in Nederland overlast van kriebelmuggen verwachten? 25

Vraag 33: Hoe zit het met dazen in Nederland? 25

Vraag 34: Kunnen we in Nederland overlast van dazen verwachten? 25

$\begin{array}{ll}\text { 3. Conclusies } & 27\end{array}$ 


\section{$1 \quad$ Inleiding, doel en werkwijze}

\section{$1.1 \quad$ Achtergrond}

De neerslag van stikstof (stikstofdepositie) is één van de belangrijkste belemmeringen om de Europese natuurdoelen te halen. De huidige neerslag in een groot aantal Natura 2000-gebieden is veel hoger dan leefgebieden van planten en dieren kunnen verdragen. Het Programma Aanpak Stikstof (PAS) moet de gevolgen van te veel stikstof, door bijvoorbeeld mest, in Nederland oplossen.

De provincie Overijssel is eindverantwoordelijk voor de PAS-maatregelen in Overijssel. Voor elk Natura 2000-gebied is een aanwijzingsdocument opgesteld, met hierin de doelen (instandhouding of uitbreiding van habitattypen en leefgebieden van soorten). Deze doelen moeten bereikt worden met beheers- en herstelmatregelen en staan per Natura 2000-gebied beschreven in een gebiedsanalyse en een beheerplan. In beide beleidsstukken zijn kaarten opgenomen waarop is aangegeven waar in het gebied maatregelen moeten worden uitgevoerd en binnen welke termijn. Daarnaast staan in de beheerplannen ook maatregelen die niet voortkomen uit de PAS, maar verband houden met regulier natuurbeheer, ontsnippering, beleid rondom andere (economische) activiteiten die in of rondom het natuurgebied plaatsvinden (landbouw, recreatie, natuuractiviteiten, delfstoffenwinning, jacht). Binnen het samenwerkingsakkoord "Samen werkt beter (Swb)" is het programma Ontwikkelopgave N2000 opgezet. Het programma Ontwikkelopgave N2000 zorgt voor het uitvoeren van de maatregelen zoals deze zijn opgenomen in de beheerplannen. In het samenwerkingsverband werken alle relevante partijen in het landelijk gebied samen om de Natura2000-opgave te realiseren, waarbij aandacht is voor een goede balans tussen ecologie en economie. Een bijzonderheid hierbij is dat naast de provincie Overijssel, ook meerdere Swb partners trekker zijn van één of meer gebiedsprocessen.

Vanwege de uitvoering van PAS-herstelmaatregelen worden de komende jaren projecten uitgevoerd waarbij onder meer:

- Vernatten van (grond)waterafhankelijke natuur (habitattypen, soorten), o.a. door dempen/verondiepen van sloten, verwijderen drainage, etc. Hierdoor kan water gedurende een korte of langere tijd op maaiveld komen te staan;

- Aanleg van waterretentiegebieden in de bovenloop van beken om beken langer watervoerend en met een hoger waterpeil te laten zijn, waarmee meer tegendruk kan worden geleverd aan uittredend grondwater;

- Aanleg van waterbergingsgebieden in de benedenloop van beken om inundatie van omliggende agrarische gronden en van kwetsbare habitattypen te voorkomen bij hoosbuien;

- Aanleg van bufferstroken met randdammen, zodat retentiebekkens ontstaan op plaatsen waar hellende agrarische percelen natuurgebieden raken, om te voorkomen dat nutriëntrijk water van agrarische percelen natuurgebieden instroomt.

Zodra het definitieve pakket aan PAS-herstelmaatregelen per N2000-gebied bekend is, wordt het maatregelenpakket vastgelegd in een inrichtingsplan, dat juridisch en planologisch wordt geborgd in bestemmingsplannen of (bij forse wijzigingen) in Provinciale Inpassingsplannen (PIP). 


\subsection{Probleemstelling}

Door bovengenoemde hydrologische of vernattingsmaatregelen kunnen er plekken ontstaan waar stagnant water gedurende een korte of een wat langere tijd op of aan maaiveld staat. De aanleiding voor dit rapport komt voort uit de inspraakreacties op twee voorontwerp-PIP's, te weten N2000-gebied Dinkelland en N2000-gebied Landgoederen Oldenzaal. Deze inspraakreacties hadden betrekking op het mogelijk optreden van steekmuggen- of knuttenoverlast als gevolg van de vernattingsmaatregelen, specifiek ook in relatie tot het optreden van dierziekten (Schmallenberg, Blauwtong, Vogelgriep, etc.). De Provincie verwacht dat in andere gebieden waar de komende tijd voorontwerp-PIP's voor gemaakt worden, dergelijke vragen te verwachten zijn.

De Provincie wil graag meer kennis over steekmuggen, knutten, dazen en kriebelmuggen binnenhalen, om zo een gedegen en onderbouwde reactie te kunnen geven op dergelijke inspraakreacties. Daarnaast wil de Provincie deze informatie omzetten in een 'deskundigenrapport' wat bij een eventuele rechtsgang aan de Raad van State kan worden overhandigd. Met dit rapport moeten mogelijke vragen omtrent steekmuggen en knutten, die in combinatie met vernattings- en retentiemaatregelen kunnen worden verwachten, beantwoord kunnen worden.

\subsection{Vraagstelling en doel}

De Provincie wil graag concrete en zoveel mogelijk gekwantificeerde antwoorden op de belangrijkste vragen rondom steekmuggen en knutten.

Het onderzoek heeft als doel 'het geven van compleet beeld ('best available knowledge') van conclusies en aanbevelingen, in de vorm van antwoorden op vragen, over de aanwezigheid en (over)last van steekmuggen en knutten in relatie tot de PASherstelmaatregelen in N2000-gebieden'.

\subsection{Werkwijze}

Deze studie is uitgevoerd als korte bureaustudie gebaseerd op bestaande en snel beschikbare kennis.

De antwoorden zijn gebaseerd van direct beschikbare (grijze) literatuur. Een belangrijk deel van de informatie in de antwoorden is afkomstig en soms direct overgenomen uit de rapporten 'Steekmuggen (Culicidae) in de Engbertsdijksvenen' (Verdonschot et al. 1988) en 'Verkenning van de steekmuggen- en knuttenproblematiek bij klimaatverandering en vernatting' (Verdonschot 2009). Daarnaast zijn delen overgenomen uit de vier artikelen: Bloedzuigende insecten deel 1. Steekmuggen. (Verdonschot 2012a), Bloedzuigende insecten deel 2. Knutten (Verdonschot 2012b), Bloedzuigende insecten deel 3. Dazen. (Verdonschot 2013a) en Bloedzuigende insecten deel 4. Kriebelmuggen. (Verdonschot 2013b).

Waar nodig is aanvullend gezocht naar nieuwe direct beschikbare kennis over de periode 2009-nu. 


\title{
2 Vragen en antwoorden over stekende insecten
}

\author{
Vraag 1: Wat is de verspreiding van steekmuggen en knutten in \\ Nederland?
}

Er komen 37 soorten steekmuggen en meer dan 103 soorten knutten voor in Nederland (Beuk 2002). De meeste soorten komen min of meer verspreid over geheel Nederland voor. Er bestaan echter geen verspreidingskaarten van de diverse soorten steekmuggen en knutten in Nederland. Er zijn ook geen landsdekkende inventarisaties uitgevoerd. Van een groot aantal knuttensoorten is nauwelijks iets bekend over de ecologie en verspreiding. Ook zijn hoogstwaarschijnlijk niet alle soorten knutten bekend die in Nederland daadwerkelijk voorkomen.

Steekmuggen ontwikkelen zich meestal in oppervlaktewateren met een grote dynamiek in milieuvariabelen, zoals temperatuurswisseling, uitdroging, organische verontreiniging en een wisselend zuurstofgehalte. Dit in tegenstelling tot veel van hun potentiële predatoren, die dergelijke milieus vermijden. Knutten ontwikkelen zich in een groot scala aan habitats, van natte organisch rijke graslanden, tot moerassen tot aan diepe meren.

\section{Vraag 2: Waar leven de larven van steekmuggen en knutten?}

Broedgebieden zijn de plaatsen waar steekmuggen en of knutten hun eitjes afzetten en waar de larven zich ontwikkelen tot volwassen dieren. De eitjes kunnen door zowel steekmuggen en knutten worden afgezet op natte grond of op oppervlaktewater. Dit is soort afhankelijk. De larven van steekmuggen leven altijd in de waterkolom, die van knutten in de waterkolom, de natte oeverzone, het litoraal of in natte gronden. Steekmuggen en knutten hebben beide een popstadium dat zich ontwikkelt in hetzelfde milieu als de larve. De volwassen dieren leven in het terrestrische milieu. De leefgebieden van volwassen steekmuggen en knutten bestaan vaak uit houtige of opgaande gewassen waar een hoge luchtvochtigheid heerst en waar prooien aanwezig zijn.

Om de informatie van broed- en leefgebieden overzichtelijk te houden zijn de steekmuggen en knutten ingedeeld in ecologische groepen. In de discussies rondom de steekmuggen en knutten problematiek in vernattingsgebieden spelen deze ecologische groepen steekmuggen en knutten een belangrijke differentiërende rol.

Huissteekmuggen ontwikkelen zich in alle semipermanente, temporaire en antropogene wateren. Het betreft meestal kleine, vaak tijdelijke waterpartijen (vrijwel alle tijdelijke wateren, emmers, badkuipen, regentonnen, blikjes, autobanden, dakgoten en overige antropogene waterpartijen) met sterke wisselingen in milieuomstandigheden. Voorbeelden zijn sterk organisch belaste wateren of wateren met een korte bestaansduur, zoals regenwaterplassen. Predatoren ontbreken in deze wateren.

De ontwikkeling van de moerassteekmuggen is sterk gebonden aan waterpeilfluctuaties. De larven leven in temporaire moeras- en drassituaties (meestal in geïsoleerde, ondiepe wateren zoals moerassen, greppels en inundatiezones). Het tijdelijk droogvallende substraat (meestal semipermanent en geïsoleerd van permanente water), al dan niet beschaduwd door bomen/hogere begroeiing en met veel organisch materiaal op de bodem waardoor mogelijk lage zuurstofconcentraties optreden en een arme gemeenschap aan overige insecten en ongewervelden (weinig predatoren aanwezig), dient als locatie voor het afzetten van de eitjes die overwinteren. Deze situatie kan het gevolg zijn van een weinig doorlatende ondergrond, eventueel in combinatie met een terreinreliëf waarin water stagneert, of een meer doorlatende of 'lekkende' ondergrond in combinatie met een tijdelijk hogere grondwaterstand. 
Slootsteekmuggen ontwikkelen zich in allerlei permanente, stilstaande, ondiepe wateren (sloten, kanalen, poeltjes, plassen) met veel ondergedoken of emergente vegetatie (vooral drijvende draadalgen en kroossloten of sloten met een ruige oevervegetatie (achterstallig onderhoud)) en in verlandende sloten en verlandingszones. De wateren hebben een diverse gemeenschap van overige insecten en ongewervelden. Een rijke vegetatie dient als schuilmogelijkheid om een te grote predatiedruk te vermijden. De larven hebben geen ademhalingsbuis en hangen horizontaal tegen het wateroppervlak en voeden zich in tegenstelling tot andere steekmuggen ook aan het wateroppervlak.

Plantenboorsteekmuggen ontwikkelen zich aan dieper groeiende emergente (boven het water uitstekende) water- en oeverplanten. De larve boort in zachte plantendelen en blijft aan de plant aangehecht. Het betreft vaak kraagvegetaties van lisdodde, riet, liesgras en dergelijke.

De boomholtesteekmuggen, ook wel containersteekmuggen genoemd, danken hun naam aan de oorspronkelijk habitat, de boomholte. Boomholtesteekmuggen ontwikkelen zich in boomholten rijk aan blad en water. Predatoren ontbreken in deze kleine wateren. Deze groep kan zich echter in allerlei zeer kleine, tijdelijke wateren ontwikkelen, waaronder autobanden, blikjes, schaaltjes, boomholten, regentonnen, dakgoten en overige antropogene waterpartijen met een hoog organisch stofgehalte en met sterke wisselingen in andere milieuomstandigheden. De eieren ontwikkelen zich wanneer een dergelijk 'micro'-oppervlaktewater zich met water vult, bijvoorbeeld na een regenbui. Bij voldoende hoge temperaturen vliegen de larven na korte tijd uit. Boomholtesteekmuggen komen ook voor in permanente 'containermilieus', waar ze meerdere generaties ontwikkelen waarbij ook predatoren aanwezig kunnen zijn die de aantallen slechts enigszins verlagen.

Knutten ontwikkelen zich afhankelijk van de soort in allerlei habitats, zoals mest, mierennesten, rottend hout, plantensappen, meren, oeverzones, rivieren, temporaire wateren, boomholten, natte graslanden, laagveenwateren, brakke en zoute wateren en zoute bodems. Overlast voor mensen wordt vooral veroorzaakt door soorten uit het geslacht Culicoides. Dit geslacht ontwikkelt zich eveneens in een brede range aan habitats.

\section{Vraag 3: Waar leven volwassen steekmuggen en knutten?}

Voor volwassen steekmuggen zijn opgaande (al dan niet lijnvormige) houtige en hoge kruidachtige begroeiingen aantrekkelijk om te schuilen en geschikt om zich doorheen te verplaatsen. De begroeiing biedt bescherming tegen wind en wordt over het algemeen gekenmerkt door een hoge luchtvochtigheid (geschikt microklimaat). Hiermee vormt de begroeiing een verbindingszone tussen de plaats waar de larven zich ontwikkelen en eventuele gebieden waar prooien zich ophouden (waaronder bebouwing), waar de vrouwtjesmuggen op zoek gaan naar een bloedmaaltijd. Het verspreidingsvermogen van steekmuggen verschilt per soort. Sommige soorten kunnen zich in halfopen terrein verspreiden, terwijl andere soorten sterk gebonden zijn aan bossen. Deze laatste groep van volwassen steekmuggen mijden open terrein volledig, onder andere vanwege de lagere luchtvochtigheid en de invloed van wind. Sommige soorten steekmuggen dringen ook woonhuizen binnen maar dit geldt lang niet voor alle soorten. Volwassen vrouwtjes van sommige soorten huissteekmuggen overwinteren op vochtige plekken in huizen (bijvoorbeeld kruipgaten), schuren en andere bouwwerken.

\section{Vraag 4: Komen steekmuggen en knutten ook voor in beken?}

Steekmuggen zijn voor hun ontwikkeling afhankelijk van stilstaand water, ze komen niet voor in stromende wateren. De larven en poppen van steekmuggen zijn zeer gevoelig 
voor stroming en golfslag, en worden wanneer dit optreedt in hun ontwikkeling beperkt. In grotere oppervlaktewateren met een brede ondiepe oeverzone zal tussen de oevervegetatie nauwelijks stroming of golfslag optreden. In deze delen is de aanwezigheid van predatoren (zoals roofkevers, libellenlarven en amfibieën) een belangrijkere factor die de ontwikkeling van de steekmuggen beperkt.

Knutten komen in allerlei wateren voor. Stroming en golfslag spelen echter een geringe rol ten aanzien van het voorkomen, behalve indien daadwerkelijk sprake is van stroming, omdat ze meestal in het bodemsubstraat leven. De oeverzone is voor veel soorten geschikt.

\section{Vraag 5: Waarom zijn steekmuggen en knutten vaak talrijk in moerasgebieden?}

Moerassen kenmerken zich door een sterke afwisseling tussen droog en nat in ruimte en tijd. Deze afwisselingen zijn een gevolg van een rond maaiveld wisselende waterstand in een reliëfrijk terrein. Met het reliëf van het terrein wordt een afwisseling van hogere en lagere delen van het maaiveld bedoeld. Deze afwisseling kan van nature aanwezig zijn (zoals langs beken en rivieren, in duinvalleien en moerasgebieden) of het gevolg zijn van inrichtingsmaatregelen (zoals plaggen of onregelmatig afgraven). Langs grotere beken en rivieren kan door erosie en sedimentatie tijdens inundaties ook een bepaald reliëf ontstaan. In vernattings- en moerasgebieden ontstaat reliëf als gevolg van bultvorming door de aanwezige (ruigte)vegetatie. Tijdens perioden met veel neerslag of na inundatie kan water achterblijven in laagten, putjes en kuilen in dergelijk reliëfrijk terrein. De verblijftijd van het water is afhankelijk van de doorlaatbaarheid van de bodem en de terreinhelling (deze laatste factor vooral in vlakke gebieden). Wanneer veel kleiafzettingen in de bodem aanwezig zijn, kan water lange tijd blijven staan. Bestaat de bodem voornamelijk uit zand, dan zal het water sneller inzijgen, behalve wanneer sprake is van een hoge grondwaterstand (bijvoorbeeld zo hoog als het maaiveld). Wanneer in het voorjaar plassen en poelen langer water bevatten, is dit in het voordeel van steekmuggen in het ondiepe water en voor knutten in de natte drogere delen. In combinatie met de ontwikkeling van hogere vegetatie (hogere luchtvochtigheid en windluwte) is dit een gunstige uitgangssituatie voor hoge(re) aantallen steekmuggen en knutten.

\section{Vraag 6: Komen er ook steekmuggen voor in een vijver met permanent water?}

In open water houden predatoren (zoals vissen, amfibieën, roofkevers, libellenlarven, enz.) de populaties van steekmuggen klein. Echter als er een verlandingszone of breed en dicht begroeide oeverzone in een water aanwezig is kunnen stekende insecten wel talrijker optreden. Verlanding van ondiepe oppervlaktewateren en oeverzones bevorderen de ontwikkeling van de habitat voor steekmuggen en knutten. Tussen de dichte submerse en emergente watervegetaties hebben larven van steekmuggen namelijk meer schuil- en ontsnappingsmogelijkheden voor predatoren. Ondiepe delen warmen daarnaast ook sneller op, hetgeen de groeisnelheid van larven van steekmuggen sterk bevordert. In de droog-nat overgangen van oeverzones gedijen knuttenlarven uitstekend, vooral als er veel organisch materiaal aanwezig is.

\section{Vraag 7: Op welke plaatsen gedijen steekmuggen goed?}

Een sterke wisseling van milieuomstandigheden, bijvoorbeeld een afwisseling van zout (brak) naar zoet water of van neutraal naar een lage zuurgraad, heeft tot gevolg dat de meeste waterdieren sterven. Met een wisseling naar brak of zoet wordt een nieuw watermilieu gecreëerd waar, als gevolg van afwezigheid van predatoren, steekmuggen 
zich goed in kunnen ontwikkelen. Extreme milieus zoals regentonnen en natte kruipgaten leveren een voor veel aquatische organismen onleefbaar milieu op, maar een habitat dat echter wel weer zeer geschikt is voor steekmuggen.

Een ander type extreem milieu zijn plaatsen waar het tijdelijk nat en tijdelijk droog is, zoals oversstromingsgebieden enerzijds tot aan containermilieus anderzijds. Het moment in de tijd, de frequentie en de duur van inundatie (in feite het water bevatten) in samenhang met het terreinreliëf of vorm van het waterhoudend bekken/object zijn sterk bepalend voor de permanentie van het achterblijvende water. Overstroming van rivieruiterwaarden en beekbegeleidende gronden treedt vooral op in de winter en het voorjaar (beek- of rivierinundatie) maar kan bij extreem nat weer in de zomer ook voorkomen. In onregelmatige terreinen met een slecht doorlatende bodem (veen- en kleigebieden, zoals veel aanwezig in de laagveenregio in het westen van Nederland) of terreinen met een hoge grondwaterstand (bijvoorbeeld duinvalleien, laagten en veenweidepolders) treden als gevolg van intense neerslag in de zomer ook (regen)inundaties op. Water zal in vlakke gebieden na (regen)inundatie langer aanwezig blijven, zeker in onregelmatig terrein. Wanneer gedurende langere tijd water in een terrein achterblijft, biedt dit een semipermanent milieu dat geschikt is voor de ontwikkeling van steekmuggen. Dit geldt ook voor alle containermilieus, zoals bekertjes, boomholten, emmers, kruipgaten, regenwatergoten, enz.

\section{Vraag 8: Wat is de rol van droogval bij optreden van steekmuggen en knutten?}

De permanentie of omgekeerd de mate van droogval van een oppervlaktewater wordt bepaald door de neerslag, de grondwaterstand, en de mate en frequentie van inundatie. Op basis van waterdiepte en hydrologische isolatie van een al dan niet tijdelijk oppervlaktewater zijn verschillende watertypen te onderscheiden.

In permanente oppervlaktewateren, zoals plassen, boezems, nooit droogvallende sloten, kanalen, beken of rivieren, kunnen populaties van predatoren van steekmuggen hun levenscyclus voltooien en door predatie zorgen dat steekmuggen zich niet massaal kunnen ontwikkelen. Steekmuglarven zijn uiterst kwetsbaar voor predatie, mede omdat ze zich vaak aan het wateroppervlak bevinden. Ook in tijdelijk onder water staande terreinen die met permanente wateren verbonden zijn, kunnen steekmuglarven zich moeilijk ontwikkelen, omdat deze toegankelijk zijn voor predatoren uit het permanente water. Een permanent nat moeras kan dus ook arm zijn aan larven van steekmuggen doordat predatoren kunnen overleven en grazen.

Geïsoleerde semipermanente en temporaire oppervlaktewateren hebben een geringe waterdiepte en zijn niet verbonden met permanente oppervlaktewateren. Dergelijke oppervlaktewateren hebben een grote kans om jaarlijks droog te vallen. Droogvalling is bij uitstek een gunstige uitgangspositie voor de ontwikkeling van grote aantallen steekmuggen. Als gevolg van droogval delen de steekmuggen het water met weinig andere organismen, dit is gunstig voor steekmuggen, omdat de larven een uiterst geringe concurrentiekracht hebben. Ook kunnen de meeste predatoren van steekmuglarven hun levenscyclus niet voltooien in droogvallende wateren en ontbreken dan ook. Lage concurrentie en predatie leiden tot het massaal optreden van steekmuggen in dit type wateren.

Knutten leven vaak in de oeverzone van permanente wateren of in natte gronden waar het water bijna het gehele jaar, en vooral in de winter en het voorjaar, aan maaiveld staat. In dit habitat leven weinig predatoren en kunnen knuttenlarven gedijen. 


\section{Vraag 9: Hoe ver verspreiden steekmuggen en knutten zich?}

Van veel Nederlandse soorten stekende insecten is de vliegcapaciteit niet bekend. Het verspreidingsvermogen van steekmuggen verschilt per soort. Sommige soorten kunnen zich verspreiden in halfopen terrein, terwijl andere soorten sterk gebonden zijn aan bossen en open terrein geheel vermijden. Overlast gerelateerde of niet-georiënteerde vluchten zijn soort specifiek en bestrijken afstanden tussen $25 \mathrm{~m}$ en $6 \mathrm{~km}$ voor 23 geanalyseerde soorten (Verdonschot \& Lototskaya 2013). Steekmuggen zijn in 4 groepen vliegers te verdelen: sterke $(>3 \mathrm{~km})$, goede $(>800 \mathrm{~m})$, matige $(400-800 \mathrm{~m})$ en zwakke (tot $400 \mathrm{~m}$ ) vliegers. Knutten behoren veelal tot goede en sterke vliegers. De vliegcapaciteit wordt beïnvloed door de landschapsstructuur, meteorologische omstandigheden (temperatuur, vochtigheid en verlichting) en de fysiologie van de soort (beschikbare energie voor de vlucht).

$\mathrm{Er}$ is een mismatch tussen ecologische groepen van huissteekmuggen, slootsteekmuggen, moerassteekmuggen en plantenboorsteekmuggen en de vier vlieggroepen. Met andere woorden: binnen iedere ecologische groep van steekmuggen kunnen zowel zwakke als sterke vliegers zitten. Voorspellingen over overlast kunnen alleen worden gemaakt wanneer soort en dichtheid van stekende dieren, prooidichtheid en structuur van het landschap tussen broedplaats en doelgebied (bv. bebouwing) bekend zijn. Dit laatste resultaat betekent dat het van de lokale omstandigheden afhangt of het inrichten van een barrière, een voor stekende insecten ongunstige structuur in het landschap (zoals open water of een korte grazige vegetatie) zinvol is omdat het van de lokale omstandigheden afhangt welke soort zich ontwikkelt. Wanneer bekend is welke soort of soorten zich ontwikkelen of kunnen ontwikkelen en welke vliegcapaciteit die hebben, kan pas aangegeven worden of een barrière meer of minder effectief zal zijn. Bosmoerassteekmuggen bijvoorbeeld zijn zwakke vliegers en daartegen kan een smalle barrière al veel effect oogsten.

\section{Vraag 10: Hoe snel en wanneer ontwikkelen steekmuggen en knutten zich?}

De levenscyclus van steekmuggen en knutten wordt gekenmerkt door een zogenaamde volkomen gedaantewisseling (metamorfose). Het insect (larve) dat uit het ei komt, verschilt morfologisch en fysiologisch volledig van het volwassen dier van de soort. Om het volwassen stadium te bereiken is een ruststadium nodig (pop), gedurende welke de omvorming plaats vindt. De eieren kunnen zich in 2-10 dagen ontwikkelen. De larve doorloopt 4 stadia en ontwikkelt zich in 1 tot 8 weken. Steekmuggen en knutten ontwikkelen zich, zoals de meeste organismen, sneller bij hogere temperaturen. Ondiepe wateren warmen in de zomer snel op en vormen daarmee een uitstekend milieu voor de zich dan zeer snel (tot binnen 10 dagen) ontwikkelende steekmug. Opeenvolgende jaren met warme zomers kunnen de omvang van de aanvangspopulaties doen toenemen. De levenscyclus ziet er bij de ecologische groepen enigszins verschillend uit en zo hun respons op temperatuur.

De huissteekmug overwintert als volwassen dier en heeft 4-6 generaties nodig om tot hoge aantallen te komen. De optimum temperatuur ligt voor de larve tussen 24$27^{\circ} \mathrm{C}$. De larven ontwikkelen zich bij gunstige temperatuur in circa 8 dagen tot volwassen dier. De dieren komen van april tot -november voor.

Moerassteekmuggen overwinteren als ei en ontwikkelen zich het meest gesynchroniseerd in het voorjaar waarbij hoge aantallen kunnen worden bereikt. Soms treedt een tweede (en mogelijk meer) generatie in de nazomer op. De volwassen dieren leven 4-6(8) weken. De optimum temperatuur ligt voor de larve bij circa $25^{\circ} \mathrm{C}$. Bij hogere temperaturen ontwikkelen ze zich sneller maar liggen de aantallen lager. De larvale 
ontwikkeling is 8-10 dagen bij warm weer tot twee maanden bij koud weer. De dieren komen van mei tot -september voor.

Slootsteekmuggen ontwikkelen zich vanaf het voorjaar (mei) en bereiken de hoogste aantallen (circa $3^{\text {de }}$ generatie) in de nazomer (hogere temperaturen; juliseptember). Ze overwinteren als volwassen dieren.

Plantenboorsteekmuggen overwinteren als larve, dicht bij de bodem vastgehecht aan de wortels van waterplanten. De soort heeft maar een generatie per jaar. De dieren komen van mei tot -september voor.

Boomholtesteekmuggen overwinteren als ei maar overleven droogteperioden eveneens als ei. Wanneer water aanwezig is ontwikkelen de eitjes zich snel.

Knutten ontwikkelen zich bij hoge temperaturen $\left(28-30^{\circ} \mathrm{C}\right)$ in $3-4$ weken tot volwassen dier. De meeste soorten van het genus Culicoides ontwikkelen zich bij 20$25^{\circ} \mathrm{C}$ in circa 1 maand van ei (in 4-6 dagen), via larf (in 20-25 dagen), via pop (in 3-5 dagen) tot volwassen dier (Gutsevich 1973). Deze volwassen dieren leven 1-2 maanden. De gehele levenscyclus neemt daarmee ongeveer 1.5 maand (range 2-6 weken) in beslag. De meeste knutten overwinteren in het derde of vierde larvale stadium, soorten met maar een generatie per jaar vaak als ei.

Overigens is de kans aanwezig dat met de klimaatverandering het 'warmere' seizoen wordt opgerekt van nu mei tot en met september tot straks april tot en met oktober.

\section{Vraag 11: Wat is de invloed van voedselrijkdom op de ontwikkeling van larven?}

Veel wateren in agrarisch gebied zijn door uitspoeling van landbouwkundige meststoffen in meer of mindere mate voedselverrijkt geraakt (eutrofiëring). Verrijking met voedingsstoffen leidt onder andere tot een sterk wisselende zuurstofhuishouding. Hierdoor treden periodes op waarin het water zeer weinig zuurstof bevat. Steekmuggen hebben onder zuurstofarme condities meer overlevingskansen ten opzichte van veel andere waterdieren, zoals hun predatoren. Dit is het gevolg van een aangepaste ademhaling. Steekmuglarven zijn namelijk in staat via een adembuis zuurstof uit de lucht te gebruiken. Eutrofiëring leidt ook tot meer algenontwikkeling en eventueel een groter aantal dierlijke micro-organismen. Beide dragen bij aan een verhoogd voedselaanbod voor de steekmuglarven.

Saprobiëring (=verrijking met dood organisch materiaal) treedt op wanneer organisch materiaal in een oppervlaktewater terecht komt. In geval van lozingen is er vaak sprake van het plotseling optreden van voor steekmuggen gunstige zuurstofarme omstandigheden. In poelen en greppels in bosgebieden leidt bladval tot saprobiëring. In deze wateren vormt het organisch materiaal ook de basis voor het voedsel voor veel steekmuggen, namelijk de bacteriën en algen die op deze bladeren voorkomen.

Samenvattend betekent dit dat naarmate de voedselrijkdom in een water hoger is er meer voedsel en minder concurrentie voor de steekmuggen is. Hierdoor worden steekmuggen bij toenemende voedselrijkdom talrijker.

De larven van aquatische knutten leven voornamelijk als predatoren op kleine dieren zoals chironomiden, steekmuglarven, kokerjuffers, nematoden, rotiferen, wormen, protozoën of andere knuttenlarven (kannibalisme). Er zijn ook soorten die zich voeden met - dood organisch materiaal, algen of bacteriën. De aquatische larven zijn goede en snelle zwemmers. Larven van aquatische knutten worden vooral door vissen gegeten. Semi-terrestrische larven bevinden relatief ondiep $(2-5 \mathrm{~cm})$ in de bodem en worden door vogels gepredeerd (Blackwell \& King 1997). Ook larven van knutten ontwikkelen zich afhankelijk van het voedselaanbod. Bij een hogere voedselrijkdom gaat de ontwikkeling sneller en meer larven bereiken het popstadium. 
Vraag 12: Hoe groot is de actieradius van steekmuggen en knutten? In vraag 9 is al ingegaan op de vliegcapaciteit van steekmuggen en knutten. $\mathrm{Er}$ is een onderverdeling gegeven in 4 groepen vliegers te weten: sterke ( $>3 \mathrm{~km}$ ), goede (>800 $\mathrm{m}$ ), matige (400-800 m) en zwakke (tot $400 \mathrm{~m}$ ) vliegers. Maar de dieren vliegen vaak niet verder dan noodzakelijk omdat vliegen ook een risico inhoudt. De feitelijk actieradius van steekmuggen en knutten is sterk afhankelijk van lokale omstandigheden. De paring treedt meestal op tijdens soortspecifieke paarvluchten die plaats vinden in de omgeving van de broedplaats. Na de paring gaan soorten die bloed nodig hebben voor de ei-rijping op zoek naar prooi. De actieradius die dan wordt bestreken is erg variabel. De huissteekmug Culex pipiens bijvoorbeeld heeft een beperkte actieradius van circa 30 m. Echter lokale omstandigheden van luchtvochtigheid, temperatuur, licht (zoals de schaduw van bomen), wind, topografie, vegetatietype of begroeiing, plaats van de broedplaats, aanwezigheid van prooien, fysiologie van het individu, vliegcapaciteit, en populatiedichtheid hebben belangrijke invloed op de daadwerkelijk afgelegde afstand. In het algemeen is de normale actieradius vrij onafhankelijk van de wind omdat vliegen bij hogere windsnelheden wordt vermeden en gecompenseerd op 'windstille' dagen. Veel meteorologische factoren hangen samen met de begroeiing. Veel stekende insecten vliegen dan ook tussen de vegetatie vlak bodem de grond of in de toppen.

Becker et al. (2003, 2010) onderscheiden drie groepen:

- Soorten die meestal opgroeien, rusten en eieren afzetten in de nabije afstand van hun prooien en die dus gewoonlijk korte afstanden afleggen (huissteekmuggen, boomholtesteekmuggen).

- Soorten die matig lange afstanden afleggen tussen de broedplaatsen, rustplaatsen en prooihabitats (sommige moeras- en slootsteekmuggen en plantenboorsteekmuggen).

- Soorten die redelijk lange tot lange afstanden afleggen tussen de verschillende habitats (sommige moerassteekmuggen (vooral soorten die hun broedplaats in open gebieden, zilte moerassen en langs rivieren hebben).

Knutten komen in alle drie de groepen voor.

Vraag 13: Welke invloed heeft het weer (bv. wind) op de actieradius? Steekmuggen en knutten worden sterk door de weersomstandigheden gestuurd. Wind, luchtvochtigheid (incl. neerslag) en temperatuur zijn de sturende weersfactoren bij de verspreiding van volwassen steekmuggen en knutten. De volwassen dieren zoeken altijd warmere, vochtigere windarme plaatsen op omdat het gevaar van uitdrogen zoveel mogelijk wordt vermeden. Een hogere temperatuur leidt tot een snellere groei en ontwikkeling. Hogere temperaturen leiden echter tot lagere luchtvochtigheid en dus risico op uitdroging. Vegetaties bieden een vochtiger microklimaat t.o.v. open vlaktes en worden daarom door volwassen steekmuggen en knutten geprefereerd. Wind leidt tot passieve verspreiding als de windkracht groter is dan de vliegkracht van het dier. Steekmuggen en knutten vermijden sterke wind door tussen de vegetatie of vlak boven de grond te gaan vliegen (Snow 1982). Steekmuggen zijn voor hun steekactiviteit afhankelijk van reukpluimen die door de wind worden getransporteerd. Windsnelheden van $0.3-1.0 \mathrm{~m} / \mathrm{s}$ verminderen succesvolle oriëntatie, zeker voor zwakke vliegers (Gillies \& Wilkes 1981, Bidlingmayer et al. 1995). De hoogste windsnelheden waarin steekmuggen vlogen variëren van 0.8-2.8 m/s voor subarctische soorten (Grimstad \& DeFoliart 1975, Bidlingmayer et al. 1995). Wind kan de actieradius van stekende insecten aanmerkelijk verkleinen. 


\section{Vraag 14: Hoe verspreiden volwassen stekende insecten zich i.r.t. begroeiing?}

Voor volwassen steekmuggen en knutten zijn opgaande (al dan niet lijnvormige) houtige en hoge kruidachtige begroeiingen aantrekkelijk om te schuilen en geschikt om zich doorheen te verplaatsen. De begroeiing biedt bescherming tegen wind en wordt over het algemeen gekenmerkt door een hoge luchtvochtigheid (geschikt microklimaat). Hiermee vormt de begroeiing een verbindingszone tussen de plaats waar de larven zich ontwikkelen en eventuele bebouwing, waar de vrouwtjesmuggen op zoek gaan naar een bloedmaaltijd. Het verspreidingsvermogen van steekmuggen verschilt per soort. Sommige soorten kunnen zich in halfopen terrein verspreiden, terwijl andere soorten sterk gebonden zijn aan bossen. Deze volwassen steekmuggen mijden open terrein volledig, onder andere vanwege de lagere luchtvochtigheid. De rol van de begroeiing is dus afhankelijk van de soort steekmug of knut.

De afstand waarover steekmuggen zich op eigen kracht verspreiden is variabel. Wanneer er open terrein tussen menselijke bebouwing, recreatieverblijven of stallen en het leefgebied van steekmuggen aanwezig is, blijft het aantal 'overstekende' stekende insecten vaak beperkt, omdat maar weinig volwassen dieren deze gebouwen zullen bereiken. Wanneer het gebied tussen broedplaats en bebouwing steekmug- en knutonvriendelijk wordt ingericht gaat het tussenliggende gebied als barrière werken. De aanwezigheid van vee in het tussenliggend gebied van broedplaats en bebouwing speelt hierbij geen rol van betekenis. Een ruime afstand tussen mogelijke broedgebieden van steekmuggen en knutten en bebouwing (de plaats waar de volwassen stekende insecten naar toe vliegen) kan effectief werken tegen bepaalde soorten en overlast beperken. Barrières verminderen altijd het aantal stekende insecten dat woningen of dierverblijven bereikt altijd. De effectiviteit van barrières (de daadwerkelijke aantalsvermindering) hangt echter samen met drie verschillende aspecten: de vliegcapaciteit, de staat van het tussenliggende gebied en de geschiktheid van het broedgebied.

De vliegcapaciteit is van veel Nederlandse soorten stekende insecten niet bekend. Van sommige knutten is bekend dat het zeer goede vliegers zijn. Daarbij is er, zoals eerder opgemerkt geen een-op-een relatie tussen ecologische groepen en vlieggroepen m.a.w. binnen iedere ecologische groep kunnen zowel zwakke als sterke vliegers zitten. Dit laatste resultaat betekent dat het van de lokale omstandigheden afhangt of een barrière zin heeft, omdat het van deze omstandigheden afhangt welke soort zich ontwikkelt. Wanneer bekend is welke soort of soorten zich ontwikkelen of kunnen ontwikkelen en welke vliegcapaciteit die hebben, kan pas aangegeven worden of een barrière meer of minder effectief zal zijn. Bosmoerassteekmuggen bijvoorbeeld zijn zwakke vliegers en daar kan een smalle barrière al veel effect oogsten terwijl riviermoerassteekmuggen sterke vliegers zijn waar barrières niet tegen werken.

Ook speelt de afstand en inrichting van het tussenliggende gebied of de barrière een belangrijke rol. De overlast veroorzaakt door zwakke en matige vliegers kan met smallere barrières, die op een juiste manier zijn ingericht, worden beperkt. Een barrière van $50-70 \mathrm{~m}$ geeft een $90 \%$ vermindering in aantallen zwakke vliegers terwijl dit bij matige vliegers met $140-200 \mathrm{~m}$ wordt bereikt. Voor de goede en sterke vliegers zijn veel bredere barrières nodig om een $90 \%$ vermindering te bereiken.

Omgekeerd als de geschiktheid (oppervlak en kwaliteit) van het broedgebied verre van optimaal is en er dus maar lage aantallen steekmuggen/knutten optreden is een $90 \%$ reductie niet nodig om toch geen overlast te krijgen.

In het algemeen is de inrichting van een barrière erop gericht om een lage luchtvochtigheid (te bereiken met zeer korte vegetatie of open water) en vrijheid voor windwerking (wind beperkt de vliegmogelijkheden sterk) te bereiken. Verplaatsingsmogelijkheden (corridors) in de vorm van linten van bosschages of 
opgaande ruigten tussen broedplaatsen en bebouwing (woningen, recreatiebedrijven, stallen) moeten onderbroken of verwijderd worden. Een extra versterking van een barrière is het aanleggen van bosschages aan de binnenzijde van het broedgebied om volwassen steekmuggen en knutten juist het gebied in te trekken i.p.v. het gebied uit richting bebouwing,te laten vliegen. Deze zogenoemde 'muggenbosjes' versterken de barrièrewerking.

\section{Vraag 15: Hoe beïnvloedt een broedgebied de aantallen stekende insecten?}

De habitataard en -kwaliteit en het oppervlak van broedplaatsen is van groot belang bij de inschatting van aantallen steekmuggen en knutten. Het ligt voor de hand dat hoe groter de oppervlakken aan potentieel broedgebied, hoe groter de kans op overlast zal zijn omdat er dan meer larven volwassen worden. Als dan ook de habitatkwaliteit van de specifieke broedplek optimaal is dan kunnen zich nog hogere aantallen stekende insecten ontwikkelen. Vaak zijn wisselend droog-natte situaties of voedselrijke wateren met wisselend zuurstofloos-zuurstofrijke omstandigheden, dus dynamische landschapstypen, de belangrijkste bon voor overlast van steekmuggen, omdat daar kwaliteit en kwantiteit van broedgebied het hoogst zijn. Dynamische omstandigheden treden bijvoorbeeld ook op na afgraven of plaggen omdat op dergelijke 'maagdelijke' locaties nog geen predatoren leven. Voor knutten is het moeilijker te definiëren wanneer de kwaliteit van het broedgebied het hoogst is, maar het hangt samen met grondwater aan maaiveld en voedselrijkdom.

Een ander voorbeeld bij oppervlak zijn de broedplaatsen van slootsteekmuggen, die vooral te vinden zijn in permanente oppervlaktewateren met veel plantengroei of flabontwikkeling. De ruimtelijk spreiding van dergelijke vegetaties zal in gebieden met sloten vaak beperkt zijn terwijl een grote, brede moeraszone langs een meer aanzienlijk kan zijn.

\section{Vraag 16: Wanneer is sprake van overlast?}

Wanneer we spreken over overlast wordt voor menselijke overlast niet gerefereerd aan ziekten maar aan aantallen steken. Ieder mens ervaart overlast verschillend en wordt ook in verschillende mate gebeten. Overlast vanuit veterinair oogpunt is wel gekoppeld aan het optreden van ziekten of verwondingen. Bij ziekten is het gekoppeld aan overdracht door stekende insecten en dat is minder duidelijk gekoppeld aan aantallen terwijl verwondingen juist direct samenhangen met aantallen. Bij de risicoanalyse op steekmuggen en knutten is het begrip overlast wel van groot belang. Een referentienorm voor overlast is voor Nederland niet opgesteld. Belangrijk is daarom een bestaande situatie zo kwantitatief mogelijk vast te stellen om deze in de toekomst met de nieuwe situatie te kunnen vergelijken.

Als vertegenwoordigers uit de families van de steekmuggen en knutten zich massaal ontwikkelen, kunnen deze plaatselijke overlast veroorzaken. Bij overlast is sprake van: 'het hinderlijk voorkomen van één of meer organismen voor mens, gewas of bezit'. Onder een plaag wordt verstaan: 'het in zulke grote aantallen aanwezig zijn van één of meer organismen, dat ze schade veroorzaken of dreigen te veroorzaken voor de mens, zijn gewassen of zijn bezittingen'. Of een organisme overlast of een plaag veroorzaakt, hangt niet zozeer af van zijn aantal, als wel van de mate waarin het schade (overlast) veroorzaakt. Ook organismen die in geringe aantallen voorkomen, kunnen overlast of een plaagsituatie teweegbrengen. Voor een massale ontwikkeling van steekmuggen en knutten zijn een aantal randvoorwaarden nodig. De volgende voorwaarden dragen bij aan overlast en plaagvorming:

a. een gunstig leefmilieu; 
b. een geringe dichtheid van parasieten en predatoren;

c. een voldoend voedselaanbod;

d. een bepaalde aanvangspopulatie van plaaginsecten;

e. pathogenen (ziekteverwekkers) die muggen en of knutten als vector kunnen overdragen.

\section{Vraag 17: Dragen steekmuggen ziekten over?}

Vector-overdraagbare ziekten worden veroorzaakt door pathogenen of ziekteverwekkers, die tussen dieren en/of mensen worden overgebracht door steekmuggen en knutten, de zogenaamde vectoren. Steekmuggen zijn bekende vectoren voor een groot aantal van de ziekteverwekkers wereldwijd. Echter in Nederland hebben zich sinds de uitroeiing van malaria eind jaren ' 50 geen epidemieën meer voorgedaan van ziekten die door steekmuggen worden overgedragen. Er komen hier echter wel steekmuggen voor die in potentie ziekteverwekkers kunnen overgedragen.

Malaria is in Nederland aan het einde van de vijftiger jaren uitgeroeid. Sindsdien hebben zich geen uitbraken meer voorgedaan van ziekten die door steekmuggen worden overgedragen. De momenteel in Nederland aanwezige soorten steekmuggen spelen vooralsnog geen rol van betekenis in de verspreiding van ziekten onder mens of dier (Braks \& Stroo 2016). Dat betekent niet dat er in potentie geen ziekteverwekkers kunnen worden overgedragen. Van de 37 in Nederland aanwezige steekmuggensoorten is van slechts enkele aannemelijk dat ze geen rol spelen in de overdracht van ziekten. Daarom heeft het toenmalige Ministerie van Volksgezondheid, Welzijn en Sport (VWS) het Rijks Instituut voor Volksgezondheid en Milieu (RIVM) gevraagd om samen met het Centrum Monitoring Vectoren (CMV) een beleidsadvies te schrijven over de mogelijke verspreiding door steekmuggen van voor Nederland nieuwe ziekten voor mens en dier. Een belangrijk deel van deze mogelijke verspreiding hangt samen met kennis van de vector; de steekmug. In het advies is een inschatting gemaakt van mogelijk humane pathogenen die kunnen worden overgedragen (Braks \& Stroo 2016). Na evaluatie van verschillende aspecten van mogelijke risico's noemt de nota vier belangrijke overdraagbare ziekteverwekkers: vivax-malaria, Westnijlkoorts, Riftdalkoorts, Francisella tularensis (tularemie).

Vivax-malaria, veroorzaakt door de protozo Plasmodium vivax, is een infectieziekte die uitsluitend bij mensen voorkomt en die wordt overgebracht door de inheemse slootsteekmug Anopheles atroparvus, een soort binnen het complex An. maculipennis s.I. Deze soort is niet in staat om $P$. falciparum, verwekker van de meer ernstige vorm van malaria, over te brengen. Het aantal gevallen waarin dragers van $P$. vivax in Nederland terugkeren is zeer laag en in combinatie met het nog slechts zeldzaam voorkomen van de vector An. atroparvus, die in brak water leeft, en de goede Nederlands gezondheidszorg wordt het risico als zeer laag ingeschat. Wanneer alle feiten in acht genomen worden lijkt de kans dat malaria op korte termijn terugkeert in Nederland verwaarloosbaar (Braks \& Stroo 2016).

Het WestNijlVirus (WNV), de veroorzaker van Westnijlkoorts, wordt gehandhaafd in een cyclus tussen vogels en huissteekmuggen (vooral soorten in het geslacht Culex). De laatste 15 jaar is het optreden van Westnijlkoorts in Europa sterk toegenomen maar er zijn geen aanwijzingen dat er WNV-overdracht in Nederland heeft plaatsgevonden (Braks \& Stroo 2016). Duijster et al. (2016) concluderen: "Gezien de lage kans op introductie van het West-Nijlvirus door trekvogels en de lage muggendichtheid in het voorjaar is het risico op introductie en vestiging van dit virus in Nederland laag (Tran et al. 2014). Daarnaast wordt de kans op vestiging, verspreiding en overdracht van het virus op mensen in Nederland beperkt door de temperatuur. Temperatuur is nu zeker een beperkende factor, maar misschien niet de enige. Zelfs als 
de temperatuur stijgt in de toekomst, is dit geen garantie dat een West-Nijl-cyclus op gang komt in Nederland".

Riftdalkoorts (Rift Valley fever of RVF) wordt door steekmuggen overgedragen op zoogdieren (incl. de mens) en vooral herkauwers, niet op vogels. In Europa is er nog nooit een uitbraak van RVF geweest (Braks \& Stroo 2016). Deze auteurs concluderen dat "het moeilijk is te zeggen wat de kans op een uitbraak in Nederland is. Naast de aanwezigheid van de juiste vectoren/insecten zijn er ook andere factoren, zoals de insleep van het virus of de temperatuur, van invloed op het ontstaan van een uitbraak. Het is aannemelijk dat RVF zich kan vestigen in Europa en in Nederland".

Tularemie wordt veroorzaakt door Francisella tularensis, een bacterie die in veel landen in Europa voorkomt. Er ontbreekt echter in Europa en ook in Nederland nog veel kennis over de rol die steekmuggen spelen in de overdracht.

\section{Vraag 18: Hoe gevaarlijk is de loodgrijze malariamug?}

De loodgrijze malariamug (Anopheles plumbeus) kwam oorspronkelijk als larve alleen voor in boomholtes. Dit bijzondere en kleine habitat leidde ook nooit tot grote dichtheden. De soort heeft zich echter aangepast aan een nieuw habitat, namelijk gierkelders en mestgoten van verlaten stallen. In deze ruimten blijven vaak resten van mest achter en deze mest mengt zich met opwellend grondwater of insijpelend regenwater. Hierdoor ontstaat een habitat wat vergelijkbaar is met een boomholte, schoon water op een organisch rijke bodem, echter met een veel groter oppervlak. In dit habitat blijken zich zeer hoge aantallen larven te kunnen ontwikkelen. Overigens vindt verspreiding van 'kelder' naar 'kelder' alleen plaats door volwassen vrouwtjes die eitjes afzetten en niet door andere vectoren. Dit habitat ontstaat vaak enkele jaren na het leegpompen van de kelder of goot. Mensen in een straal van circa 500-1000 m rondom de broedplaats worden zowel overdag als in de schemering gestoken. De overlast is in dergelijke zones groot.

Van de loodgrijze malariamug is met zekerheid bekend dat ze onder laboratoriumomstandigheden in staat is om de tropische malariaparasiet $P$. falciparum over te brengen. Echter de zeer lage contactkans tussen loodgrijze malariamug en een besmette patiënt maakt de kans op een uitbraak minimaal (Braks \& Stroo 2016). De toename in aantal casussen en de overlast van deze soort vraagt echter wel bijzondere aandacht.

\section{Vraag 19: Welk percentage knutten is drager van Blauwtong en Schmallenberg?}

De laatste decennia hebben uitbraken van door knutten van het geslacht Culicoides overdraagbare veterinaire ziekten voorgedaan in Nederland, zoals Blauwtong en Schmallenberg (beide virusziekten). Knutten zijn echter in staat een groot aantal virussen over te dragen. Naast de genoemde zijn dit onder andere Lumpy Skin Disease (LSD), Akabane virus (AKAV), Equine Encephalosis Virus (EEV), Afrikaanse paardenpest (APP) en Epizootic Haemorrhagic Disease (EHD).

Het BlauwTongVirus (BTV) veroorzaakt de dierziekte blauwtong en wordt overgedragen door Culicoides knutten. Er zijn wereldwijd 24 serotypes van het BTV bekend, waarvan de meeste vooral voorkomen in tropische en subtropische gebieden. De meeste types blauwtong geven hoofdzakelijk ziektetekens bij herkauwers. Tot 2006 kwamen in Europa alleen de serotypen 1, 2, 4, 9 en 16 voor. Het serotype 8 is in ons land en de rest van Europa sinds 2006 opgedoken en veroorzaakt niet alleen ziektesymptomen bij schapen, maar ook bij runderen. Bij de uitbraak van blauwtong serotype 8 in NW Europa in 2006 en 2007 is bewezen dat de knuttensoorten C. obsoletus, C. dewulfi, C. pulicaris en C. chiopterus BTV kunnen overbrengen. Deze 
soorten maken een belangrijk deel uit van de knutten die voorkomen in het landelijk agrarisch gebied. Knutten overwinteren meestal als ei. Het virus wordt niet via eitjes overgedragen. Dat betekent dat het virus niet tot nauwelijks voorkomt tijdens de winterperiode. Pas als in het voorjaar knutten besmette dieren steken kan besmetting optreden en begint overdracht. Soms overwinteren volwassen knutten in zeer lage aantallen en ook blijft het virus minstens 60 dagen aanwezig in besmette dieren. Dat zijn twee routes waarlangs het virus de winter kan doorkomen. Grote aantallen besmette knutten komen alleen voor na een periode van doorgifte en bij herhaald steken. De bestrijding van blauwtong in Nederland is gebaseerd op Europese regelgeving, en vaccinatie is hierbij een belangrijk onderdeel.

Het Schmallenbergvirus (SBV) werd in 2011 voor het eerst in Europa vastgesteld. Het virus veroorzaakt aangeboren afwijkingen bij kalveren en lammeren. Inmiddels is bekend dat zowel gehouden als in het wild levende herkauwers gevoelig voor het SBV. Het virus wordt overgedragen door knutten (Culicoides species). Vooral de soorten Culicoides obsoletus complex en Culicoides dewulfi die gevangen zijn in 2011, bevatten hoge concentraties SBV (Elbers et al. 2013). In Nederland en België waren de gevonden virusconcentraties vijf tot tienmaal hoger dan werd gezien bij blauwtong (van der Poel 2013). Het lijkt erop dat met SBV geïnfecteerde dieren (tijdelijk?) een goede immuniteit ontwikkelen tegen de ziekte. Sinds de komst van het SBV circuleert het jaarlijks. De kans op een uitbraak hangt echter af van het aantal knutten dat zich in de loop van het jaar ontwikkelt en de besmettingsgraad van die knutten. Over dat laatste is echter weinig bekend. Ook het SBV wordt niet via knutteneitjes overgedragen en de aantallen aanwezige besmette knutten is vergelijkbaar met blauwtong besmettingen.

\section{Vraag 20: Levert vernatting extra risico op voor vogelpest?}

Vogelpest is een ziekte veroorzaakt door het influenza A-virus en die voorkomt bij vogels, voornamelijk hoenderachtigen. Het virus kan zich verspreiden door de lucht, via direct contact tussen vogels en indirect via bijvoorbeeld uitwerpselen en transportmiddelen. Het virus wordt niet door steekmuggen of knutten overgedragen.

Het Usutuvirus daarentegen is een virus waar vogels ziek van kunnen worden. Het virus wordt door steekmuggen, voornamelijk uit het geslacht Culex, overgedragen. Vermoedelijk is het virus door trekvogels vanuit Afrika naar Europa overgebracht. Ondanks de grote uitbraken onder vogels, zijn in Europa van slechts enkele mensen met een verlaagde weerstand bekend dat ze besmet waren met het Usutuvirus.

\section{Vraag 21: Zijn inentingen en preventieve maatregelen mogelijk?}

In het algemeen kunnen veehouders preventieve maatregelen nemen om de kans op besmetting met virussen overgebracht door knutten te verkleinen, door bijvoorbeeld de kans dat hun dieren in aanraking komen met de knutten, te verminderen. Dit kan door de dieren in de schemering en 's nachts op te stallen en door insecticiden te gebruiken.

Blauwtongvirus: Een echte behandeling voor blauwtong bestaat niet: tegen het veroorzakende virus is geen medicijn beschikbaar. Virus remmende middelen zijn er voor herkauwers evenmin. Vaccinatie is het enige echt effectieve middel bij hoefdieren. Het vaccin is alleen effectief tegen het serotype-8 en -1(?). Niet uitgesloten kan worden dat er een ander type blauwtong de kop opsteekt. Het vaccin biedt in dat geval geen bescherming. Blauwtong is niet overdraagbaar op de mens.

Schmallenbergvirus: Uit onderzoek van het RIVM blijkt dat het zeer onwaarschijnlijk is dat mensen ziek worden van het Schmallenbergvirus. Er is op dit moment geen vaccin of medicijn beschikbaar. Een vaccin is wel in ontwikkeling.

Usutuvirus: Er zijn geen specifieke medicijnen beschikbaar. De behandeling van vogels bestaat uit het bestrijden van de symptomen. Een vaccin voor vogels is 
vooralsnog niet beschikbaar. Het is zeer uitzonderlijk dat mensen met het Usutuvirus besmet raken. In de zeldzame gevallen dat dit gebeurde betrof het personen met verzwakte weerstand.

\section{Vraag 22: Levert vernatting extra overlast op voor recreanten?}

Vernatting van een gebied kan het risico vergroten dat steekmuggen en knutten talrijker gaan optreden. De factoren en processen die dat risico bepalen kunnen worden beoordeeld. Het betreft factoren of processen die van invloed zijn op de vorming van habitats, inclusief het aanwezig zijn van hun predatoren, die geschikt zijn voor de verschillende levensstadia van steekmuggen en knutten. Hiertoe is de 'Leidraad Risicomanagement overlast steekmuggen en knutten' (Verdonschot \& Lototskaya 2012) ontwikkeld (bijlage 1). Met deze tool kunnen de risico's van inrichtingsmaatregelen worden ingeschat.

In Nederland is geen onderzoek gedaan naar de relatie tussen recreatieve activiteiten en de mate van aanwezigheid van overlast veroorzakende stekende insecten. Internationaal is wel een verband aangegeven tussen beide zaken, waarbij de tijd dat mensen in een dergelijk gebied verkeren korter is bij overlast. Veel inheemse steekmuggen zijn vooral in de ochtend- en avonduren actief en hebben daardoor overdag geen invloed op recreatieve activiteiten. Alleen de dagactieve soorten, zoals de tijgermug, leveren wel overlast. Uit onderzoek in twee dorpen in Italië bleek dat het percentage geïnterviewde personen dat aangaf minder activiteiten in de open lucht te ontplooien in het dorp Rovigo, een gebied met een hoge dichtheid van de tijgermug ( $A$. Albopictus) $54 \%$ bedroeg ten opzichte van $31 \%$ in het dorp Villadose (Carrieri et al. 2008).

Knutten daarentegen zijn dagactief en kunnen in hoge dichtheden voorkomen. Van veel laagveengebieden in Nederland is bekend dat in de periode half mei-half juni waterrecreatie gehinderd wordt door hoge aantallen knutten. In het Verenigd Koninkrijk is deze overlast nog erger en wordt van een 'midge-season' gesproken (Kettle 1951, Boorman 1986, Blackwell 2000). Bosarbeiders zijn in die periode circa $20 \%$ minder effectief (Hendry \& Godwin 1988). De overlast wordt vooral door de knut C. impunctatus veroorzaakt (Blackwell \& Page 2003), een soort die ook in Nederland wijd verspreid is. Hoge aantallen $C$. impunctatus zijn negatief gecorreleerd met veedichtheid, maar positief met lichtbegraasd grasland of natte biezen (de habitat van de larve; Purse et al. 2012). Vergelijkbare overlastsituaties zijn van alle continenten bekend (Marsh 1986).

In het algemeen is de belangrijkste remedie het gebruik van een DEET-houdend middel tijdens openluchtrecreatie.

\section{Vraag 23: Waardoor is er vaak sprake van overlast rond bebouwing?}

De bebouwde of urbane omgeving omvat woonhuizen, recreatieverblijven, bedrijven, kantoorpanden, boerderijen met stallen en hun directe omgeving. Juist voor steekmuggen en knutten speelt de bebouwde omgeving een belangrijke rol. Veel tijdelijke restwatertjes blijven op en rondom bebouwing achter en fungeren zo als een tijdelijk watermilieu dat uitermate geschikt is voor steekmuggen. Vochtige graslanden zijn uitermate geschikt voor de culicoide knutten. Verschillende watertypen aanwezig rondom bebouwing kunnen worden onderscheiden.

Permanent water met zoninval, zoals vijvers, drinkpoelen en bassins zijn vergelijkbaar met ondiep open water mits het niet, zoals soms bij bassins het geval is, regelmatig droogvalt of wordt leeggepompt.

Permanent van licht afgesloten water, zoals regentonnen, ondergrondse bergingen en kruipruimten, ontvangen geen licht wat de ontwikkeling van een 
watersysteem met daarin rovers en andere organismen hindert. Het is een biologisch relatief 'leeg' maar permanent oppervlaktewater.

Tijdelijk water omvat droogvallende kunstmatige waterpartijen zoals die ontstaan in oude badkuipen en drinkbakken. Het peil is sterk wisselend en er treedt op onregelmatige tijden droogval op.

Onvoorzien water betreft zeer kleine tot grotere waterpartijen die vaak na perioden met neerslag ontstaan in bijvoorbeeld autobanden, bloembakken, emmers, speciekuipen, jampotjes, verstopte dakgoten, slecht afwaterende platte daken, depressie in afdekplastics, enz.

\section{Vraag 24: Treedt er verschil op tussen de bestaande en toekomstige natuur?}

Deze vraag betreft het verschil tussen de bestaande situatie (droogvallende beken en vennen, verdroogde blauwgraslanden, kalkgraslanden, trilvenen, etc.) en de nieuwe situatie (waterretentiegebieden, waterbergingsgebieden, vernatting, etc.) en het aantal steekmuggen en knutten die in de nieuwe situatie extra te verwachten zijn.

Door het uitvoeren van de verschillende vernattingsopgaven worden eveneens grotere delen van gebieden meer geschikt als leefmilieu voor steekmuggen en knutten. Vooral de gebiedstypen van moeras, plas-dras en nat grasland zijn van belang in een dergelijke toename. De vraag is echter of deze toename ook aanleiding geeft voor extra overlast. Wanneer sprake is van natuurdoelen dan betreft dat vaak het nastreven van stabiele milieu-omstandigheden in hydrologie (bijvoorbeeld het ontwikkelen van hoogveen betekent het stimuleren van de groei van veenmossen, wat weer betekent dat de hydrologie nauwelijks wisselingen mag vertonen). Ook betekent het soms het nastreven van matig tot zeer voedselarme omstandigheden en soms het creëren van waterbergingsgebieden, waterretentiegebieden en bufferstroken met randdammen die juist voedselrijker zijn en slechts tijdelijk water bevatten (instabiele milieuomstandigheden). Naarmate de voedselrijkdom afneemt zal het aantal stekende insecten dat zich kan ontwikkelen worden beperkt. Dit geldt minder voor de aan voedselarmere omstandigheden aangepaste soorten, maar die profiteren juist van een hydrologische dynamiek. Stabiliteit in milieu-omstandigheden is in het algemeen zeer ongunstig voor het talrijk worden van stekende insecten, instabiliteit juist niet. Belangrijk bij ieder project is of stabiliteit ook daadwerkelijk kan worden gerealiseerd of dat juist instabiliteit ontstaat. De deelvraag over toename in aantallen of indicatie daarvan is dus niet eenduidig te beantwoorden en is weer locatie en omstandigheden specifiek. De mate van stabiliteit en voedselrijkdom bepaald in belangrijke mate de aanwezigheid van specifieke soorten en van toe- of afnames.

Vraag 25: Zijn maatregelen mogelijk als er gegronde risico's ontstaan? Bij het herinrichten of nieuw aanleggen van natte terreinen staat altijd voorop 'het voorkomen van situaties waar massale ontwikkeling van steekmuggen en knutten kan plaats vinden'. Voor een verantwoorde (her)inrichting geldt daarbij dat kennis van de ecologie van mogelijk optredende soort(en) steekmuggen en of knutten noodzakelijk is om een locatie specifieke risicoanalyse vooraf mogelijk te maken. Bij de (her)inrichting van gebieden is vooraf vaak ook sprake van een vraag naar het potentieel optreden van steekmuggen en knutten. Deze vraag kan worden beantwoord wanneer naast de potentieel optredende steekmuggen en knutten ook kennis is over de bij (her)inrichting gewenste en vanuit optiek van steekmuggen en knutten mogelijke fysische (habitatstructuur en waterhuishouding), chemische (waterkwaliteit, voedselrijkdom) en biologische milieu-omstandigheden. 
Daarnaast zijn ook aanvullende maatregelen op gebied van fysieke inrichting, waterkwantiteit en waterkwaliteit mogelijk om bij te sturen.

\section{Vraag 26: Hoe kan ik op fysieke omstandigheden (bij)sturen?}

Bij het (her)inrichten van natte gebieden wordt altijd ingegrepen op de fysische omstandigheden van het terrein en het houdt bijna altijd een wijziging van de structuur van het aanwezige ecosysteem in. Ten aanzien van ontwikkeling van steekmuggen en knutten zijn hierbij twee uitersten mogelijk. Enerzijds het voorkómen of verminderen van het ontstaan van oppervlaktewater (vooral tijdelijke aquatische milieus) en anderzijds het volledig en permanent onder water zetten (van delen) van een gebied. Dit zijn vaak doeltreffende methoden gebleken om omvangrijke leefmilieus van steekmuggen en knutten te minimaliseren. Het nadeel bij het voorkómen van grote drassige oppervlakken en moerassen of het egaliseren van potentieel drassige terreinen is dat hierdoor ook de temporaire aquatische milieus zelf met hun eigen flora en fauna verdwijnen. Bij het volledig onder water zetten van deelgebieden geldt hetzelfde nadeel, echter door het graven van bijvoorbeeld sloten en plassen kan nog een redelijke aquatische diversiteit ontstaan.

Bij de aanleg van permanente wateren dient rekening te worden gehouden met:

1. De potentiële ontwikkeling van waterplanten als substraat voor de plantenboorsteekmug Coquillettidia.

2. Een eventuele golfslagzone ter voorkoming van kolonisatie door Anopheles en Culex (malariamug respectievelijk huissteekmug)

3. Een steilere oever ter voorkoming van ei-afzetting door Aedes (moerassteekmug).

Dit dient echter steeds in relatie met de plaats, de aanwezigheid van predatoren, de doelstellingen en de ontwikkelingsmogelijkheden van het gebied te worden bekeken. Minder drastische mitigerende maatregelen omvatten een meer ecologische inrichting van de potentiële (tijdelijke) aquatische milieus door bijvoorbeeld:

- Het over grote afstanden voorkómen of regelmatig weghalen van overhangende vegetatie ter voorkoming van ei-afzettingsmogelijkheden voor schaduwminnende soorten.

- Het niet aanplanten of laten ontwikkelen, of het kappen van bomen en struiken waardoor de toevoer van organische voedingsstoffen voorkomen of verminderd wordt en de schuil- en dispersiemilieus voor volwassen dieren verminderen.

- Het verwijderen van watervegetatie (stevige helofyten zoals lisdodde, egelskop, kalmoes, gele lis, mannagras en dergelijke) waaraan Coquillettidia gebonden is voor de luchtademhaling.

- Het (laten) optreden van onregelmatige waterstandwisselingen waardoor tijdelijk aquatische milieus in aanraking komen met permanente milieus of juist verder indrogen. Hierbij moet wel gezorgd worden dat juist geen extra tijdelijke aquatische milieus ontstaan.

- Het eind februari instellen van een hoog waterpeil (minimaal $20 \mathrm{~cm}$ ) en in mei van een lager peil waardoor geen synchronisatie van Aedes populaties kan optreden en predatie een kans krijgt.

- Het voorkómen van brede ondiepe, onregelmatig en te flauw aflopende oevers waar veel tijdelijke aquatische milieus zich kunnen vormen.

- Het voorkómen van het optreden van teveel restwateren (kleine poelen) na waterstanddaling in het voorjaar door bijvoorbeeld het egaliseren van de flauw aflopende oevers of een steilere oevervorm.

- Het aanbrengen van voldoende waterbeweging. 
Al deze methoden hangen samen met de aanwezige ecologische kennis van de plaag veroorzakende soorten. Elke situatie vraagt om een eigen interpretatie van het aanwezige gebiedstype en de te beïnvloeden fysische factoren. Daarbij is het nodig om te weten welke soorten steekmuggen aanwezig zijn dan wel te verwachten zijn.

Timing is hierbij een extra factor. Bij waterretentiegebieden bijvoorbeeld hangt het sterk af van de door het weer gestuurde mate van natheid (het optreden van tijdelijk water) en de temperatuur. Herhaling van tijdelijk water in combinatie met hogere temperaturen bevordert bijvoorbeeld het massaal optreden van huissteekmuggen.

\section{Vraag 27: Hoe kan ik op waterkwaliteit sturen?}

Het sturen op de waterkwaliteit van het potentiële leefmilieu van steekmuggen en knutten omvat vaak drastische maatregelen, zoals:

- Het omvormen van een zoutwater in een zoetwaterhabitat of omgekeerd.

- Het omvormen van een zuur in een neutraal milieu of omgekeerd.

- Het omvormen van een voedselrijk in een meer voedselarm milieu of omgekeerd.

Dergelijke ingrepen hangen vaak nauw samen met mogelijke hydrologische maatregelen en of saneringsmaatregelen. Hierbij gelden dezelfde nadelen ten aanzien van biodiversiteitsverlies als genoemd onder sturing op habitat en waterkwantiteit. Een bijkomend risico is dat juist bij omvorming de nieuwe leefmilieus mogelijk geschikt worden voor andere soorten steekmuggen en knutten. Minder drastische inrichtingsmogelijkheden omvatten bijvoorbeeld:

- Het verminderen of stopzetten van toevoer van voedselrijk water.

- Het verminderen of stopzetten van organische belasting.

- Bij voedselrijk water het voorkomen van het ontstaan van langdurige tijdelijke wateren.

Bij het inlaten van water of wijzigen van kwelstromen moet er rekening me worden gehouden dat sulfaatrijk water kan leiden tot interne eutrofiëring (veenrot).

Vraag 28: Kan ik sturen op predatoren van steekmuggen en knutten?

Eén van de meest kansrijke biologische factoren houdt de introductie van of het scheppen van randvoorwaarden voor het optreden van predatoren om zo de aantallen larven van steekmuggen en knutten te verminderen. Meestal zijn de leefmilieus van steekmuggen en knutten ongeschikt voor kolonisatie door (potentiële) predatoren als gevolg van de aanwezige dynamische milieuomstandigheden (onder andere periodieke uitdroging, wisseling in chemische samenstelling). Het met succes doen optreden van of doen koloniseren met predatoren betekent in veel gevallen ook vermindering van een groot deel van de steekmuggen en knutten. Een voorbeeld is een (tijdelijke) koppeling aan een permanent oppervlaktewater. Specifieke predatoren van steekmuggen en knutten zijn niet bekend, maar generieke des te meer. Sommige planten (Eleocharis $s p .$, Scirpus sp.) remmen de ei-afzetting van bepaalde soorten. Het stimuleren van de ontwikkeling van deze planten kan waar mogelijk zinvol zijn.

Het sturen met predatoren op volwassen steekmuggen en knutten is veel minder kansrijk. Gebieden met hoge aantallen stekende insecten blijken niet sterk te kunnen worden uitgedund door vogels, vleermuizen of andere predatoren op volwassen dieren.

\section{Vraag 29: Moet ik extra maatregelen nemen vlak na een (her)inrichting?}

Het antwoord is ja. Bij (her)inrichting ontstaan vaak nieuwe al dan niet tijdelijke oppervlaktewateren. Dergelijke wateren zijn mogelijk nog niet gekoloniseerd met predatoren, met andere woorden: de levensgemeenschap is nog niet ontwikkeld. Dit 
biedt een ruimte voor kolonisatie van snelgroeiende soorten zoals steekmuggen. Vaak treedt na ingreep binnen korte tijd een massale ontwikkeling van steekmuggen op. Bij de (her)inrichting kan aandacht gegeven worden om dergelijke tijdelijke uitbraken te verminderen:

- Het uitvoeren van de aanleg in de nazomer waardoor meer fauna tussen de nazomer en het voorjaar van het volgende jaar tijd krijgt om het nieuwe of heringerichte milieu te koloniseren.

- Het in verbinding brengen van het nieuw aangelegde of heringerichte water met reeds bestaande permanente wateren zoals plassen of brede sloten. Deze koppeling versnelt de kolonisatie met predatoren van het (ver)nieuw(d)e milieu.

- Het monitoren van nieuw aangelegde natte gebieden om, indien daar aanleiding voor is, plaatselijk en gericht te bestrijden.

Vraag 30: Heeft het terreinbeheer invloed op steekmuggen en knutten? De uiteindelijk ontwikkelde toestand van vernat of van een om andere reden (her)ingericht gebied kan een verhoging op het aantal steekmuggen en knutten tot gevolg hebben. Echter door kleinschalige herinrichtingsmaatregelen en aanpassingen aan beheer kan overlast voor direct omwonenden worden verkleind. Een aantal mogelijkheden zijn:

- Het ervoor zorgen dat een afstand tussen nat terrein en bebouwing van 80 tot enkele honderden meters wordt gehandhaafd (zie vraag 9 en 12). In deze strook zijn geen verbindende stroken van ruigtekruiden, opgaande begroeiingen of bosschages aanwezig. Door deze corridors voor steekmuggen en knutten te vermijden zullen veel minder volwassen muggen de bebouwing kunnen bereiken. Het aanleggen van dergelijke barrières helpt altijd maar dat de effectiviteit is niet alleen afhankelijk is van (1) de soort met een bepaalde vliegcapaciteit (4 vlieggroepen), maar ook van (2) de inrichting van de buffer ('Hoe onneembaar is de barrière voor de steekmug of knut?'), (3) de aard (in relatie tot de ecologische groepen steekmuggen en knutten), het oppervlak en kwaliteit van het broedgebied en (4) de ruimtelijke positionering t.o.v. bosschages en woningen, recreatieverblijven, stallen en overige bebouwing. Dit betekent dat bovengenoemde 4 aspecten in relatie tot de weersomstandigheden, omdat die uiteindelijk de dynamiek van het water sturen, in de discussies rondom buffers en barrières meegenomen moeten worden. Deze complexiteit vraagt om een lokale benadering.

- Het ervoor zorgen dat vernatte, moerassige of plas-dras situaties op veel plaatsen - al dan niet tijdelijk - in open verbinding komen te staan met permanent open water.

- Het ervoor zorgen dat oeverzones geleidelijk aflopen naar permanent water zodat bij verlaging van het waterpeil er nauwelijks tot geen restwater achterblijft, en het water dat wel achterblijft zo gering is dat het binnen tien dagen is verdampt.

- Waar mogelijk het permanent, zeer ondiep en vaak voedselrijk en plantenrijk water te laten bewegen, bijvoorbeeld bij bemalen, om zo steekmuggen veel minder kans te geven zich te ontwikkelen.

- Het streven, ook bij moeras- en plas-dras situaties of verbrede oevers, naar stabiele, matig-voedselrijke omstandigheden. In het agrarisch gebied is water echter vaak eutroof of hypertroof. Stabiele waterecosystemen hebben een beter ontwikkelde levensgemeenschap met meer veerkracht waarin groepen zoals steekmuggen en knutten veel minder kans hebben zich massaal te ontwikkelen. Minder voedselrijke wateren zullen ook veel minder snel verlanden. 
- Begrazing door runderen of paarden vergroot het terreinreliëf. Afhankelijk van de bodemgesteldheid en vegetatiestructuur kunnen plekken (pootafdrukken, kuilen, ligplekken van vee) ontstaan waarin water achterblijft. Dit geldt vooral bij een slechte draagkracht van de bodem, bijvoorbeeld bij natte veenbodems. Begrazing onder dergelijke omstandigheden dient zoveel mogelijk te worden voorkomen.

- Ook het maaibeheer speelt een rol in het leefgebied van steekmuggen. Extensief beheerde weidegebieden hebben veelal hogere vegetaties met een hogere luchtvochtigheid en luwte, wat in het voordeel is van volwassen steekmuggen die daarin rustplaatsen vinden en zich daardoor kunnen verplaatsen.

- Verrijking van oppervlaktewater met voedingsstoffen (eutrofiëring) leidt onder andere tot een sterk wisselende zuurstofhuishouding. Steekmuggen hebben, in geval van zuurstofarme condities, door een aangepaste ademhaling meer overlevingskansen ten opzichte van veel andere waterdieren zoals hun predatoren. Voldoende strenge eisen aan de waterkwaliteit kan bijdragen aan de verkleining van de kans op steekmuggen.

- Er voor zorg dragen dat kleinere, ondiepe wateren (vaak sloten) niet te ver verlanden. De verlandingscyclus moet tijdig wordt gestopt of teruggezet door maaien een baggeren.

- Waar terreinreliëf geen rol speelt bij de functie van een gebied, kan ervoor worden gezorgd dat er minder laagten aanwezig zijn, zodat achterblijvend water na inundatie of neerslag, vooral bij slechter doorlatende bodems, zich niet in tijdelijke plasjes ophoopt.

\section{Vraag 31: Hoe zit het met kriebelmuggen in Nederland?}

Er komen 17 soorten kriebelmuggen (Simuliidae) voor in Nederland. De larven van kriebelmuggen leven in stromend water (beken en rivieren). Meestal komen ze alleen in ondiep water voor, tot op een diepte van zo'n $30 \mathrm{~cm}$ vastgehecht aan waterplanten, takken en stenen, met uitzondering van een aantal soorten dat karakteristiek is voor grote rivieren. Ze worden vooral enorm talrijk in voedselrijkere beken en rivieren waarin zich veel algen ontwikkelen. Ook worden ze in grote aantallen gevonden in overlopen en cascades na poelen, zandvangen of reservoirs. In dit stilstaande water ontwikkelen zich veel algen en bij de uitstroom vinden de kriebelmuggen de combinatie van stromend water en veel voedsel in de vorm van de algen.

Het meest opvallende aan deze stekende insecten is hun steek- of bloedzuiggedrag. Zo zijn van kriebelmuggen indrukwekkende cijfers bekend over het aantal landingen op een mens: twaalf landingen per vierkante centimeter huid per minuut met 2,6 steken tot gevolg. Dergelijke dichtheden treden vooral op als de dieren massaal gelijktijdig uitvliegen. In Nederland komen plagen in deze vorm niet voor. Behalve lokaal in de snelstromende Zuid-Limburgse beken komt ook geen overlast voor.

De levensduur van kriebelmuggen is variabel. Zo doorloopt de larve van Simulium damnosum de larvale periode in zes dagen en wordt de hele levenscyclus in minder dan twee weken voltooid. De larven vervellen zes tot negen keer (meestal zeven keer). Het aantal vervellingen is mede afhankelijk van de watertemperatuur en de voedselkwaliteit. Het popstadium duurt bij de meeste soorten ongeveer één week. De eitjes worden in pakketten van dertig tot 800 stuks afgezet. Nadat de larven uit de eitjes kruipen, verspreiden ze zich en hechten zich aan vaste substraten, zoals plantenstengels, hout of stenen. 


\section{Vraag 32: Kunnen we in Nederland overlast van kriebelmuggen verwachten?}

Kriebelmuggen zijn belangrijke verspreiders van rivierblindheid, een tropische ziekte die veroorzaakt wordt door een nematode en blindheid tot gevolg heeft. Noch in Nederland, noch in Europa worden door kriebelmuggen ziekten op de mens overgedragen. Desalniettemin kan de overlast in de omgeving van stromend water groot zijn. Langs de Donau zijn in 1923 op één dag 22 duizend stuks vee de dood ingejaagd. Echte plagen zijn in Nederland niet gedocumenteerd, wel plaatselijke overlast. Het meest hinderlijke is dat kriebelmuggen vaak in zwermen rondom iemands hoofd zwermen zonder te steken. Kriebelmuggen dragen wel enkele dierziekten over zoals bovine onchocerciasis bij vee en myxomatose bij konijnen.

Het beheer richt zich veelal op de larven. Benedenstrooms van zandvangen kan door het verwijderen van de watervegetatie of het laten wisselen van de waterstand de dichtheid van kriebelmuggen sterk worden verminderd. Normale DEET-houdende smeermiddelen beschermen de mens tegen steken.

\section{Vraag 33: Hoe zit het met dazen in Nederland?}

Dazen behoren tot de meest bekende stekende insecten. Ze zijn groot, hebben vaak opvallende kleuren en de vrouwtjes bijten overdag. Deze beet is meestal pijnlijk.

De ogen van dazen zijn opvallend met gele, oranje of paarse kleurpatronen. De kleur van het achterlijf heeft geleid tot namen zoals gele vlieg of blauwstaartvlieg, de oogkleur tot de benaming groenkop. Dazen worden in de volksmond vaak verward met horzels. Horzels behoren echter tot een andere groep van vliegen en kunnen niet steken of bijten. De larven van horzels parasiteren levende dieren, meestal hoefdieren, terwijl de larven van dazen zich in het water of op andere vochtige plekken ontwikkelen. De larven kunnen in verschillende habitats gevonden worden, bijvoorbeeld in modderbodems en rottend plantenmateriaal in allerlei watersystemen maar ook onder stenen in beken, in rottend hout of op het land in strooisel. Feitelijk zijn de meeste larven aquatisch omdat ze of in het water of in waterverzadigde bodem leven. Vaak worden de dazen op basis van de natheid van het leefmilieu ingedeeld in waterminnend, semi-waterminnend, vochtminnend en droogteminnend. De ontwikkelingsduur van de larve is afhankelijk van de voedselbeschikbaarheid, de temperatuur en de vochtigheid. Als de larve uit het ei komt vervelt ze éénmaal voordat ze gaat bewegen. De tweede vervelling vindt 3 tot 6 dagen later plaats. Daarna vinden nog 5 tot 9 vervellingen plaats. De larven kunnen maanden overleven zonder voedsel. Dazen overwinteren meestal als larve. Meestal verpoppen de dazen in het voorjaar. Het popstadium duurt, afhankelijk van de soort en de temperatuur, 1 tot 4 weken. Volwassen dazen leven ongeveer 6 weken. Dazen zijn hele goede vliegers die dagelijks kilometers kunnen afleggen. Hun verspreiding hangt vooral van de prooidichtheid af. De meeste dieren blijven echter meestal dicht bij hun broedgebied. De vliegactiviteit wordt sterk beïnvloed door het weer. Ze vliegen vooral op warme, windstille dagen. Dan wordt ook de hoogste steekactiviteit waargenomen, vooral als de lucht ook nog vochtig is. Na het bloedmaal ontwikkelen de eitjes in het vrouwtje zich in 3 tot 13 dagen. Deze worden enkele dagen later afgezet. De eitjes van dazen zijn 1 tot $3 \mathrm{~mm}$ groot en worden in klompjes van 50 tot 800 stuks afgezet, bij waterminnende soorten op blad van emergente of drijvende vegetatie (op 20 tot $70 \mathrm{~cm}$ boven het wateroppervlak) of op bladeren of bast van overhangende takken langs beken en bij landminnende soorten op kruidige vegetatie of de strooisellaag.

\section{Vraag 34: Kunnen we in Nederland overlast van dazen verwachten?}

Op enkele soorten na steken alle dazenvrouwtjes, vooral overdag. De periode van de dag waarop ze steken is afhankelijk van de soort. De belangrijkste aantrekking gaat uit 
van kooldioxide, warmte en bij sommige soorten dierlijke urine. Dazen steken vooral runderen, paarden, herten en andere grote zoogdieren, maar kunnen ook andere gewervelden zoals vogels en reptielen steken. Soms keren vrouwtjes na circa 3 dagen terug om dezelfde prooi te steken. Wanneer de bloedstroom op gang is verlaat het vrouwtje de gastheer niet meer. Door de sterke antistollingsmiddelen die de dazen uitscheiden blijft het bloed minutenlang uit de wond stromen. Dit trekt weer andere vliegen aan met extra kans op bijkomende infecties voor de gastheer. Het is ook dit antistollingsmiddel dat jeuk en bulten veroorzaakt. Het herhaald bijten leidt tot het uitwisselen van bloed tussen prooidieren en daarmee tot verspreiding van in bloed aanwezige ziekten. Na een bloedmaal blijft namelijk altijd een klein residu in de monddelen achter. Dazen kunnen virussen, bacteriën, protozoa en nematoden overbrengen. Gelukkig gebeurt dat in Nederland niet en veroorzaken dazen alleen overlast en zo nu en dan een plaag. De bijtwonden die dazen veroorzaken kunnen wel gemakkelijk geïnfecteerd raken hetgeen tot ontstekingen kan leiden. Het belangrijkste beheerprobleem is dat in een gebied bijna altijd meerdere soorten leven in verschillende habitats en dat die soorten ook nog eens actief zijn in verschillende seizoenen. Beschermende maatregelen op de huid van het vee zijn daarom alleen effectief bij continue behandeling. Ook bij mensen is het effect van insecten werende middelen, inclusief DEET-houdende stoffen, weinig effectief tegen dazen. Omdat dazen niet door kleding heen steken is voor mensen het dragen van een lange broek en kleding met lange mouwen het meest effectief om dazenbeten te voorkomen.

Voor vee is het meest effectief om de dieren in schuren te houden en niet in de buurt van overgangen tussen bos en grasland te laten grazen. Echter, gesloten omheiningen of houtwallen hoger dan $2 \mathrm{~m}$ kunnen wel de aantallen dazen beperken. Dazen vliegen namelijk niet hoog en zullen eerder om dergelijke omheiningen heen vliegen dan eroverheen gaan.

De larven bestrijden is moeilijk omdat bestrijdingsmiddelen nauwelijks in natte bodems doordringen. Waterbeheer kan bijdragen. Wanneer de soort bekend is dan kan de pop worden verdronken door op het juiste moment het grondwaterpeil te laten stijgen. Omgekeerd kan bij andere soorten verdroging uitkomst bieden. Omdat dazen vooral goed gedijen in geroerde venige gronden is het aan te bevelen bij herinrichtingen dergelijke gronden in de eerste jaren te verdrogen om de aantallen larven te beperken. 


\section{Conclusies}

Bij het uitvoeren van vernattingsmaatregelen en de aanleg van waterretentiegebieden, waterbergingsgebieden en bufferstroken met retentiebekkens kunnen er plekken ontstaan waar stagnant voedselrijk water gedurende een korte of een wat langere tijd op of aan maaiveld staat. Op dergelijke plekken kan overlast ontstaan van stekende insecten.

De Provincie Overijssel wil graag meer kennis over stekende insecten (steekmuggen, knutten, dazen en kriebelmuggen) hebben, om zo een gedegen en onderbouwde reactie te kunnen geven op inspraakreacties naar aanleiding van voorgenomen vernattings- en retentiemaatregelen. Daarnaast wil de Provincie deze informatie omzetten in een 'deskundigenrapport' wat bij een eventuele rechtsgang aan de Raad van State kan worden overhandigd.

De bovengenoemde 34 vragen en antwoorden hebben betrekking op het mogelijk optreden van overlast door stekende insecten als gevolg van de vernattings- en retentiemaatregelen. Overlast voor de mens (bewoner, recreant, campingeigenaar etc.) en overlast in relatie tot het optreden van dierziekten (Schmallenberg, Blauwtong, Vogelgriep, etc.).

Overlast voorkomen begint bij een brongerichte aanpak. De bron van overlast door stekende insecten begint daarom bij het ervoor zorgen dat deze insecten niet massaal kunnen ontwikkelen. Daarvoor moet gezorgd worden dat broedplaatsen van larven tot een minimum worden beperkt. Broedplaatsen zijn altijd locatie- en soort-specifiek. Steekmuggen ontwikkelen zich meestal in oppervlaktewateren met een grote dynamiek in milieuvariabelen, zoals temperatuurswisseling, uitdroging, organische verontreiniging en een wisselend zuurstofgehalte. Knutten ontwikkelen zich in een groot scala aan habitats, van natte organisch rijke graslanden, tot moerassen tot aan diepe meren. Dazen ontwikkelen zich in natte tot aquatische organische habitats. Kriebelmuggen leven in stromende wateren. Het massaal ontwikkelen van larven hangt altijd samen met een dynamische verstoorde omgeving.

Hoofdfactoren in het dynamische larvenmilieu zijn hydrologie, weer en water- en bodemsamenstelling. Bij vernattings- en retentiemaatregelen is vaak sprake van tijdelijk voedselrijk water. Dat water is vooral bevorderlijk voor steekmuggen en knutten. Kriebelmuggen leveren in Nederland nauwelijks overlast en dazen alleen zeer lokaal, vooral bij gewoelde natte, organische bodems. Voor steekmuggen is periode van het jaar in relatie tot water- en moerastype van belang terwijl bij knutten periode van het jaar en water tot maaiveld het belangrijkste is. Kernregels zijn het niet laten ontstaan van langdurig tijdelijke voedselrijke wateren in de zomer om huissteekmuggen en in het voorjaar om moerassteekmuggen geen kans te geven, en het zorgen dat water aan maaiveld voor half april uitzakt om knutten geen kans te geven.

Volwassen stekende insecten zoeken altijd hoog opgaande kruiden, bosschages en struikgewas op om te rusten, te ontwikkelen en te verspreiden. Op deze plekken is de luchtvochtigheid hoog genoeg om te overleven. Overlast kan daarom ook aanvullend verminderd worden door in het gebied dat tussen de maatregellocaties en de bebouwing ligt, verplaatsing van vooral steekmuggen en knutten zoveel mogelijk te beperken. Dit kan door het treffen van beheer- en inrichtingsmaatregelen zoals het inperken van hoog opkomende begroeiingen (bosschages, houtwallen, singels, ruigten in bermen, langs 
akkers en slootkanten). Door vegetaties in dit verspreidingsgebied kort te houden wordt voorkomen dat steekmuggen en knutten zich richting bebouwing kunnen verplaatsen. Omgekeerd kan het aanbrengen van opgaande begroeiing in de tegenovergestelde richting ertoe leiden dat steekmuggen en knutten juist naar de andere zijde van de vernattingsmaatregelen worden geleid.

Omdat mogelijke overlast altijd locatie- en soortspecifiek is wordt aanbevolen om bij nieuwe projecten de nulsituatie vooraf vast te leggen, de toekomstige ontwikkeling te voorspellen (uitvoeren van een risico-analyse) en na uitvoering van maatregelen te monitoren. 


\section{Literatuur}

Becker N., Petrić D., Boase C., Lane J., Zgomba M., Dahl C. \& Kaiser A. (2003). Mosquitoes and their control (Vol. 2). New York: Springer.

Becker N., Petrić D., Zgomba M., Boase C., Madon M., Dahl C. \& Kaiser A. (2010). Mosquito Research Techniques. In Mosquitoes and their Control (pp. 43-61). Springer, Berlin, Heidelberg.

Beuk P.L.T. (2002). Checklist of the Diptera of the Netherlands. KNNV Uitgeverij.

Bidlingmayer W.L., Day J.F. \& Evans D.G. (1995). Effect of wind velocity on suction trap catches of some Florida mosquitoes. J. Am. Mosq. Control Assoc. 11: 295-301.

Blackwell A. \& Page S.J. (2003). Biting midges and tourism in Scotland. Managing tourist health and safety in the new millennium, 67-84.

Blackwell A. (2000). Scottish biting midges: tourist attraction or deterrent? Antenna (London), 24(3), 144-150.

Blackwell A., \& King F.C. (1997). The vertical distribution of Culicoides impunctatus larvae. Medical and veterinary entomology, 11(1), 45-48.

Boorman J. (1986). British Culicoides (Diptera: Ceratopogonidae): notes on distribution and biology. Entomological Gazette, 1986.

Braks M.A.H. \& Stroo C.J. (2016). Bestrijding van inheemse muggen in Nederland: Mogelijkheden en uitdagingen.

Carrieri M., Bellini R., Maccaferri S., Gallo L., Maini S., \& Celli G. (2008). Tolerance thresholds for Aedes albopictus and Aedes caspius in Italian urban areas. Journal of the American Mosquito Control Association, 24(3), 377-386.

Duijster J.W., Stroo C.J. \& Braks M.A.H. (2016). Van vogels, muggen en West-Nijl-virus. Weinig kans op West-Nijl-koorts in Nederland. NED TIJDSCHR GENEESKD, 160, A9899.

Elbers A.R., Meiswinkel R., van Weezep E., et al. (2013). Schmallenberg virus in Culicoides spp. Biting midges, the Netherlands, 2011. Emerg Infect Dis. 19(1):106-9. doi: 10.3201/eid1901.121054

Gillies M.T. \& Wilkes T.J. (1981). Field experiments with a wind tunnel on the flight speed of some West African mosquitoes (Diptera: Culicidae). Bull. Entomol. Res. 71: $65-70$.

Grimstad P.R. \& DeFoliart G.R. (1975). Mosquito nectar feeding in Wisconsin in relation to twilight and microclimate. J. Med. Entomol. 11: 691-698.

Gruys P., Van Lenteren J.C., Parlevliet J.E., Scheepens P.C. en Van Zon J.C.J. (1985). Oecologische achtergronden van plagen en hun bestrijding: In: 'Inleiding tot de oecologie', Bohn, Scheltema en Holkema, Utrecht, 465492.

Gutsevich A.V. (1973). bloodsucking midges (Ceratopogonidae). Fauna SSSR Nasekomye Dvukrylye.

Hendry G. \& Godwin G. (1988). Biting midges in Scottish forestry: a costly irritant or a trivial nuisance? Scottish Forestry, 1988.

Kettle D.S. (1951). The spatial distribution of Culicoides impunctatus Goet. under woodland and moorland conditions and its flight range through woodland. Bulletin of Entomological Research, 1951.

Marsh P.M. (1986). Ecological studies on Culicoides impunctatus (Diptera Ceratopogonidae) with reference to its control in the Highlands of Scotland.

Purse B.V., Falconer D., Sullivan M.J., Carpenter S., Mellor P.S., Piertney S.B., Mordue (luntz) A.J., Albon S., Gunn G.J. \& Blackwell A. (2012). Impacts of climate, host and landscape factors on Culicoides species in Scotland. Medical and veterinary entomology, 26(2), 168-177. 
Snow W.F. (1982). Further observations on the vertical distribution of flying mosquitoes (Diptera: Culicidae) in West African savanna. Bull. Entomol. Res. 72: 695-708.

Tran A., Sudre B., Paz S., et al. (2014). Environmental predictors of West Nile fever risk in Europe. Int. J. Health Geogr. 2014;13:26.

van der Poel, W. H. M. (2013). Beheersing van het Schmallenbergvirus. Tijdschrift voor Diergeneeskunde, 138(11), 28-32.

Verdonschot P.F.M., \& Besse-Lototskaya A.A. (2014). Flight distance of mosquitoes (Culicidae): a metadata analysis to support the management of barrier zones around rewetted and newly constructed wetlands. Limnologica-Ecology and Management of Inland Waters, 45, 69-79.

Verdonschot Piet F.M (2009). Verkenning van de steekmuggen- en knuttenproblematiek bij klimaatverandering en vernatting. Alterra rapport 1856. $76 \mathrm{pp}$.

Verdonschot, P.F.M. \& A. Besse-Lototskaya (2012). Leidraad Risicomanagement overlast steekmuggen en knutten. Alterra-rapport 2298, 57 pp.

Verdonschot, P.F.M. (2012a). Bloedzuigende insecten deel 1. Steekmuggen. Dierplagen informatie 3: 4-7.

Verdonschot, P.F.M. (2012b). Bloedzuigende insecten deel 2. Knutten. Dierplagen informatie 4: 16-20.

Verdonschot, P.F.M. (2013a). Bloedzuigende insecten deel 3. Dazen. Dierplagen informatie 1: 16-19.

Verdonschot, P.F.M. (2013b). Bloedzuigende insecten deel 4. Kriebelmuggen. Dierplagen informatie 4: 6-9.

Verdonschot, P.F.M., Schmidt, G., Leeuwen, P.H.J. van \& Schot, J.A. (1988). Steekmuggen (Culicidae) in de Engbertsdijksvenen. RIN, Leersum, rapp. 88/31: 1-109.

Zadoks J.C. (1985). Landbouw tussen oecologie en economie. In 'Inleiding tot de Oecologie'. Bohn, Scheltema en Holkema, Utrecht. 375421. 


\begin{tabular}{|l|l|}
\hline Naam & $\begin{array}{l}\text { Leidraad Risicomanagement Overlast Steekmuggen en } \\
\text { Knutten }\end{array}$ \\
\hline Type & $\begin{array}{l}\text { Deze leidraad maakt het mogelijk om overlast van steekmuggen } \\
\text { en knutten vast te stellen of te voorspellen en geeft advies over } \\
\text { maatregelen. De tool is een Excel-applicatie. }\end{array}$ \\
\hline Geschikt voor projectfase & $\begin{array}{l}\text { 1) Verkenningsfase (ontwikkelen varianten); 2) vergelijken } \\
\text { varianten; 3) Ontwikkelingsfase; 4) Overlastsituaties }\end{array}$ \\
\hline $\begin{array}{l}\text { Geschikt voor projecten met } \\
\text { schaalgrootte }\end{array}$ & $<1->100$ hectare \\
\hline Geschikt voor gebied & Landelijk dekkend \\
\hline Relatie met andere tools & MCA Verondiepen \\
\hline Contactpersoon & $\begin{array}{l}\text { Piet Verdonschot: tel. 0317486552; e-mail } \\
\text { piet.verdonschot@wur.nl }\end{array}$ \\
\hline
\end{tabular}

\section{Toepassing in plantraject}

Het beoordelingsinstrument is ontwikkeld voor planvormers, inrichters en terreinbeheerders die betrokken zijn bij voorbereiding, uitvoering of begeleiding van projecten waarbij vernatting aan de orde is waardoor risico bestaat van overlast door muggen en knutten. Met dit instrument kunnen de partijen beter hun verantwoordelijkheid nemen omdat ze een eventueel risico beter in beeld krijgen en zo veel overlast kunnen voorkomen of verminderen.

\section{Omschrijving/Achtergrond}

Door het uitvoeren van de verschillende vernattingsopgaven worden meer (delen van) waterbergings- en natuurontwikkelingsgebieden geschikt als leefmilieu voor steekmuggen en knutten. Om de effecten van vernatting op de mate van ontwikkeling van steekmuggen- en knuttenpopulaties in beeld te krijgen en in de planvorming al te kunnen sturen en verminderen is door Alterra de Excel-applicatie 'Leidraad Risicomanagement Overlast Steekmuggen en Knutten' ontwikkeld. Voor het aanscherpen van de inhoud van de leidraad zijn twee enquêtes onder water- en natuurbeheerders uitgevoerd. Deze enquêtes geven inzicht in praktijkervaring met overlast en plaagvorming van steekmuggen en knutten in Nederland.

De bepalende factoren en processen die een rol spelen bij 'overlast' door steekmuggen en knutten hangen sterk samen met veel voorkomende gebiedstypen. De leidraad heeft als ingang deze gebiedstypen (landschapselementen) of natuurtypen uit de Index Natuur en Landschapstypen. De leidraad kan ingezet worden voor een geheel gebied waarbij elk landschapselement afzonderlijk wordt beoordeeld. Na een sessie wordt een geïntegreerd rapport opgesteld waarin voor alle landschapselementen de kans op overlast is berekend en relevante maatregelen zijn voorgesteld. Met het doorlopen van meerdere sessies kunnen verschillende scenario's worden doorgerekend.

Aan dit beoordelingsinstrument is een eenvoudig signaleringsprotocol gekoppeld dat door een beheerder zelf kan worden uitgevoerd. Het protocol wordt ingezet wanneer overlast wordt ervaren en geeft een eerste indruk van de (potentiële) problematiek in een specifiek landschapselement. Het signaleringsprotocol is alleen bedoeld voor gebruik in combinatie met dit beoordelingsinstrument.

De applicatie is vrij te downloaden van de website van Alterra en werkt op stand-alone en netwerkcomputers met Excel versies 2003 of later. 


\section{Noodzakelijke input/voorbereiding}

De benodigde input voor de tool is een (concept) inrichtingsplan, met een overzicht van welke landschapstypen (dit zijn of terreintypen (landschapselementen) of natuurtypen (uit de Index Natuur en Landschapstypen) worden aangelegd of ontwikkeld. Daarnaast wordt (facultatief kwalitatief) informatie gevraagd over: vorm en oppervlak van natte en waterelementen, hydrologische situatie, begroeiing per landschapselement incl. oppervlak en configuratie, terreinreliëf, bodemtype, waterkwaliteit $(\mathrm{Cl}, \mathrm{pH}$, voedselrijkdom), informatie over eventuele bebouwing, en beheer.

Vervolgens kan een sessie in de tool worden opgestart, en leidt de tool de gebruiker door een serie vragen. Na een sessie wordt een geïntegreerd rapport opgesteld waarin voor alle landschapselementen de kans op overlast is berekend en relevante maatregelen zijn voorgesteld.

Toepassing 1, variantontwikkeling

Voor het gebruik in de verkenningsfase kan de tool iteratief worden gebruikt, om tot een inrichtingsvariant te komen met zo min mogelijk risico op overlast door stekende insecten.

Toepassing 2, vergelijk planvarianten

Voor het gebruik in het vergelijken van planvarianten kan de tool per variant ingevuld worden, waarna de kans op overlast per inrichtingsvariant vergeleken kan worden. Hieruit kan het plan met de kleinste kans op overlast gekozen worden.

\section{Toepassing 3, ontwikkelingsfase}

Tijdens de ontwikkelingsfase treden vaak extra risico's op stekende insecten op door de verstoring van de bestaande situatie. Risico-analyse tijdens deze fase ondersteunt het voorkómen van overlast en geeft inzicht voor beheerder en omwonende in de mate en temporele aspecten van de risico's.

Toepassing 4, Overlastsituaties

$\mathrm{Na}$ herinrichting kunnen overlast situaties ontstaan. Om gericht de bron- of broedgebieden vast te stellen levert dit instrument kostenbesparende ondersteuning. 


\section{Voorbeeld Mariapeel}

Staatsbosbeheer en de provincies Noord-Brabant en Limburg werken al jaren aan het vernatten van de Deurnese Peel en Mariapeel om de hoogveenregeneratie te bevorderen. Omwonenden signaleren overlast van steekmuggen in de huidige situatie en een toename over de afgelopen 10 jaar. Ze plaatsen vraagtekens bij de voorgenomen

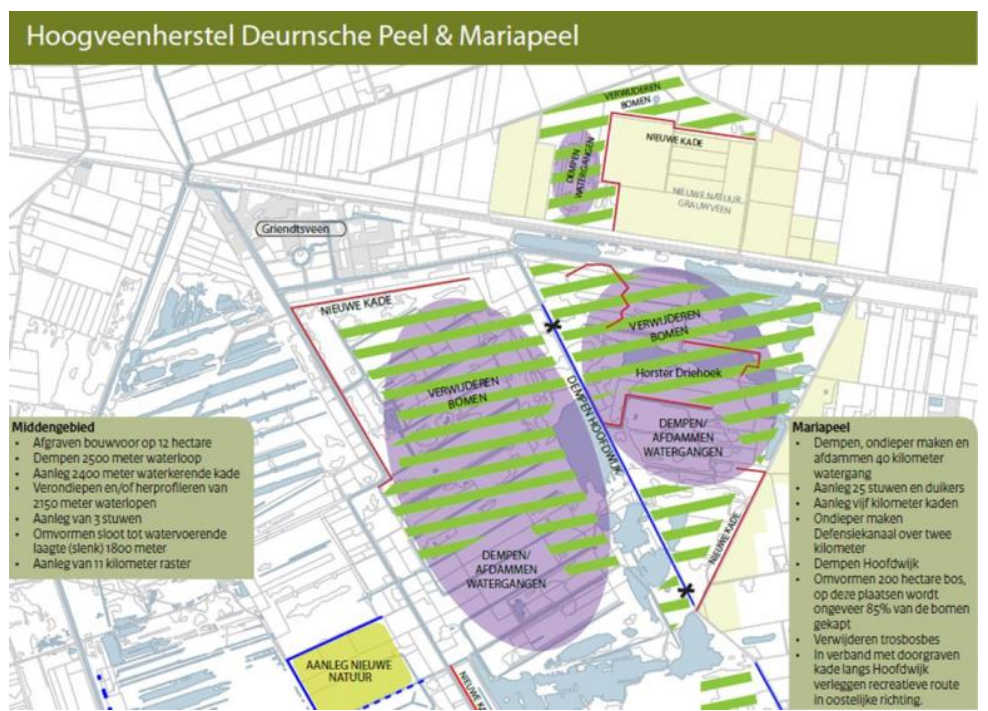

herinrichting van het deelgebied '300 Bunders'.

Figuur: Voorgenomen maatregelen Mariapeel - 300 Bunders.

Het doel van het onderzoek was het beoordelen van het herinrichtingsplan 'Vernatting Mariapeel - 300 Bunders' op de risico's op stekende insecten.

Aan de hand van gegevens van de Mariapeel is een quick-scan risico-analyse naar mogelijk overlast gevende broedgebieden van stekende insecten uitgevoerd. Het Staatsbosbeheer heeft hiertoe een kaart met vegetatietypen en informatie over de geplande herinrichting Mariapeel en aanvullende informatie aangeleverd. De vegetatietypen en de voorgenomen vernattingsmaatregelen zijn omgezet in voor stekende insecten relevante landschapstypen.

Tabel: Relatie tussen vegetatietypen en landschapstypen in de Mariapeel.

\begin{tabular}{|l|l|}
\hline Groep vegetatietypen & Landschapstype \\
\hline $\begin{array}{l}\text { Nat Berken-zomereikenbos (B1; B2; c,i en B4; } \\
\text { a,b) }\end{array}$ & nat bos/struweel \\
\hline Elzenbos (B3; b) & nat bos/struweel \\
\hline $\begin{array}{l}\text { Natte en vochtige pijpenstrootjes vegetatie (D3; } \\
\text { D4; P1; Tb2) }\end{array}$ & $\begin{array}{l}\text { plas-dras/moeras open (matig) } \\
\text { voedselarm }\end{array}$ \\
\hline $\begin{array}{l}\text { Natte pitrusruigte (R4; Tc2) } \\
\text { plas-dras/moeras open (matig) } \\
\text { voedselarm }\end{array}$ \\
\hline $\begin{array}{l}\text { Moerasvegetatie of Oeverzone met riet, gele lis } \\
\text { en/of hennegras (R1; R2; R3; R5) }\end{array}$ & moeras open voedselrijk \\
\hline $\begin{array}{l}\text { Matig voedselrijk witbolgrasland (G3; c en G4; } \\
\text { c) }\end{array}$ & vochtig grasland matig voedselrijk \\
\hline $\begin{array}{l}\text { Voedselrijk grasland met Engels raaigras (G1; } \\
\text { b,c) }\end{array}$ & nat grasland voesdselrijk \\
\hline
\end{tabular}




\begin{tabular}{|l|l|}
\hline Overstromingsgrasland $(\mathrm{O} 1 ; \mathrm{a}, \mathrm{c})$ & overstroomd grasland voedselrijk \\
\hline Open water (W1) & open water \\
\hline Open water met kroos (W5) & open water met kroos \\
\hline
\end{tabular}

Door het uitvoeren van een quick-scan per landschapstype is het gebied met behulp van de Leidraad 'Risicomanagement Overlast Steekmuggen en Knutten' beoordeeld op mogelijke overlast van stekende insecten voor omwonenden.

Tabel: Risico op stekende insecten per landschapstype

\begin{tabular}{|c|c|c|c|c|c|c|}
\hline $\begin{array}{l}\text { risicosoortgroepen } \\
\text { Landschapstypen Mariapeel }\end{array}$ & 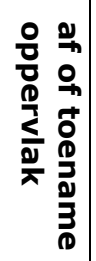 & $\begin{array}{ll}n & 3 \\
0 & 0 \\
0 & 0 \\
0 & 0 \\
3 & 0 \\
& 0 \\
0 & 1\end{array}$ & 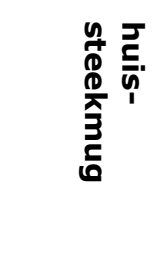 & 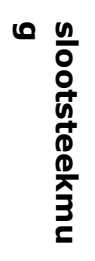 & 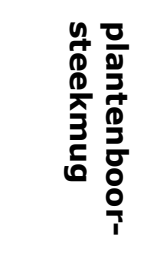 & 졸 \\
\hline Nat bos/struweel & +- & ++++ & & & & ++++ \\
\hline \multirow{2}{*}{$\begin{array}{l}\text { Plas-dras open matig voedselarm } \\
\text { Moeras open matig voedselarm }\end{array}$} & + & + & +++ & & & $++(++)$ \\
\hline & + & ++++ & + & & + & ++ \\
\hline Moeras/oeverzone open voedselrijk & - & ++++ & $+++(+)$ & + & $+++(+)$ & +++ \\
\hline Vochtig matig voedselrijk grasland & + & & & & & + \\
\hline Nat voedselrijk grasland & + & & & & & ++++ \\
\hline Overstroomd voedselrijk grasland & + & & $++(++)$ & & & ++++ \\
\hline Open water met kroos & - & & & $\begin{array}{c}++ \\
+\end{array}$ & & \\
\hline Open water & + & & & + & & \\
\hline \multicolumn{7}{|c|}{$\begin{array}{l}\text { Geen of zo nu en dan een steek. } \\
\text { Regelmatig een steek of meerdere steken in kortere periode bij buiten zitten. } \\
>1 \text { keer per } 2-3 \text { jaar en langer dan } 2-3 \text { weken niet meer lekker buiten kunnen zitten. } \\
\text { Jaarlijks } 2-3 \text { weken niet meer lekker buiten kunnen zitten. } \\
\text { Jaarlijks meerdere maanden zeer frequent gestoken worden. } \\
\text { Een incidentele plaagsituatie (zoals op Schiermonnikoog). }\end{array}$} \\
\hline
\end{tabular}

Op basis van de resultaten van de analyse is een advies geschreven met aanbevelingen voor aanvullende beheermaatregelen die genomen kunnen worden in het kader van het vastgestelde herinrichtingsplan om mogelijke overlast door steekmuggen en knutten zoveel mogelijk te beperken.

Tabel: Samenvatting aanbevolen maatregelen op basis van de risico-analyse.

\begin{tabular}{|l|c|c|}
\hline Landschapstypen Mariapeel & Maatregel & Aandacht voor \\
\hline Nat bos/struweel & constant peil & $\begin{array}{c}\text { Vermijden verbindingen, wel } \\
\text { pleksgewijs handhaven of } \\
\text { aanbrengen }\end{array}$ \\
\hline Plas-dras open matig voedselarm & begreppelen & $\begin{array}{c}\text { Tegengaan voedselverrijking, } \\
\text { geen corridors }\end{array}$ \\
\cline { 2 - 2 } Moeras open matig voedselarm & constant peil & \\
\hline
\end{tabular}




\begin{tabular}{|l|c|c|}
\hline Moeras/oeverzone open voedselrijk & constant peil, verarmen & $\begin{array}{c}\text { Doorbreken van } \\
\text { aaneengesloten corridors met } \\
\text { opgaande, gesloten houtige } \\
\text { begroeiing }\end{array}$ \\
\hline Vochtig matig voedselrijk grasland & vlak aflopend (geen reliëf) & $\begin{array}{c}\text { Vermijden van inundaties en } \\
\text { beweiden, begreppelen }\end{array}$ \\
\hline Nat voedselrijk grasland & $\begin{array}{c}\text { peilverhoging najaar } \\
\text { vlak aflopend (geen reliëf) } \\
\text { (geen zomerinundatie) }\end{array}$ & beweiden, maaien \\
\hline Overstroomd voedselrijk grasland & $\begin{array}{c}\text { vlak aflopend (geen reliëf) } \\
\text { Schonen, verarmen }\end{array}$ & beweiden, maaien \\
\hline Open water met kroos & regelmatig schonen \\
\hline
\end{tabular}

De ruimtelijke vertaling van bovenstaande maatregelen naar peilbeheer en compartimentering vormen een volgende stap in dit proces. Daarnaast is aanbevolen de omwonenden voldoende en feitelijk te informeren (voorlichtingsbijeenkomst) en om monitoring van de huidige en toekomstige situatie op te nemen in de actiepunten.

\section{Referenties}

Verdonschot, P.F.M. \& A. Besse-Lototskaya (2012). Leidraad Risicomanagement overlast steekmuggen en knutten. Alterra-rapport 2298, 57 pp.

Verdonschot P.F.M. \& Besse-Lototskaya A.A. 2011. Beoordelingsinstrument 'Risico op knutten- en muggenoverlast'. Alterra, Wageningen, Versie 1.0.

\section{Link}

http://www.wageningenur.nl/en/show/Leidraad-voor-verminderingmuggenoverlast.htm 